\title{
Late Turonian polychaete communities recorded in the hemipelagic sediments of the Bohemian Cretaceous Basin (Teplice Formation, Ohře and Dresden districts)
}

\author{
JAN SKLENÁŘ, TOMÁŠ KOČí \& MANFRED JÄGER
}

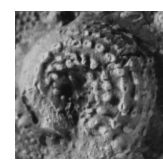

\begin{abstract}
The relatively rich sabellid and serpulid polychaete oryctocenoses of the hemipelagic Upper Turonian of the Bohemian Cretaceous Basin are hereby revised. Seven species from six genera were identified and described from the present key locality of Úpohlavy near Lovosice. Ongoing revision of previously published literature as well as the recently collected material resulted in eight polychaete species from seven genera being identified from the hemipelagic Late Turonian sediments of the basin: sabellids Glomerula plexus (J. de C. Sowerby), G. lombricus (Defrance) and serpulids Pyrgopolon (Septenaria) macropus (J. de C. Sowerby), Neovermilia ampullacea (J. de C. Sowerby), Dorsoserpula wegneri (Jäger), Serpula? (Cementula?) biplicata (Reuss), Josephella subanulata Regenhardt and Neomicrorbis crenatostriatus (Münster in Goldfuss) with the subspecies N. c. crenatostriatus. Data gained from the Úpohlavy quarry allows us not only to accomplish the revision presented here, but also deepen our knowledge of life strategies and paleoecology of the tubiculous polychaetes living in soft bottom conditions of a shallow, epicontinental sea. Among other findings the strong tendency towards a cryptic mode of life in Neovermilia ampullacea is discussed and an extraordinarily well preserved sample of Glomerula plexus reeflets network is documented. Two groups with different ecological amplitude have been recognised in the Úpohlavy polychaete communities. - Key words: Sabellidae, Serpulidae, Spirorbinae, Upper Cretaceous, palaeoecology, encrusters, soft-bottom.
\end{abstract}

SKLENÁR̆, J., KoČí, T. \& JÄGER, M. 2013. Late Turonian polychaete communities recorded in the hemipelagic sediments of the Bohemian Cretaceous Basin (Teplice Formation, Ohře and Dresden districts). Bulletin of Geosciences 88(3), 675-695 (6 figures). Czech Geological Survey, Prague. ISSN 1214-1119. Manuscript received February 1, 2013; accepted in revised form March 28, 2013; published online May 20, 2013; issued July 3, 2013.

Jan Sklenářr, Palaeontological Department, Natural History Museum, National Museum, Václavské náměstí 68, 11579 Praha 1, Czech Republic; jan_sklenar@nm.cz・Tomáš Kočí, Palaeontological Department, Natural History Museum, National Museum, Václavské náměstí 68, 11579 Praha 1, Czech Republic; Protula@seznam.cz・Manfred Jäger, Lindenstrasse 53, D-72348 Rosenfeld, Germany; langstein.jaeger@web.de

Despite almost two centuries of palaeontological research within the Bohemian Cretaceous Basin (BCB), knowledge of the polychaete fauna from the hemipelagic facies still remains limited. The first studies dealing with this topic were published by A.E. Reuss (1840, 1845-1846). From the Saxonian part of the basin worms were described by Geinitz (1839-1842, 1843, 1871-1875), followed by Frič (1889) in the Bohemian area. The first modern revision was by Ziegler (1984), but his paper was focussed on worms of the rocky-coast facies.

As most of the classical localities have vanished during the $20^{\text {th }}$ century and new outcrops are rare and ephemeral, we based our study on outcrops in the working quarry in the vicinity of Úpohlavy near Lovosice (Fig. 1). This sitethe largest section through the Late Turonian hemipelagic sediments of the $\mathrm{BCB}$ - has become an object of extensive research during the last three decades. The present study benefitted from the extensive data produced by this research.

Since the initial paper of Čech et al. (1996), knowledge of the fossil record and biostratigraphy (e.g. Ekrt et al. 2001, Wiese et al. 2004, Mikuláš 2006, Štorc \& Žítt 2008, Žítt \& Vodrážka 2008, Sklenář \& Simon 2009) as well as understanding of regional sedimentology and sequence stratigraphy, has greatly improved (Laurin \& Uličný 2004). Moreover, new data on many related topics such as geochemistry (Wiese et al. 2004, Laurin \& Uličný 2004) have been generated. Results of this long-term multi-disciplinary research provide a unique background for the present study. During the years of field work the locality has yielded numerous specimens of fossil polychaetes which provide substantial data not only for taxonomical revisions 
but also for palaeoecological interpretations. The problem of taxonomic revision of sabellid and serpulid (including spirorbine) worms from deposits of the Teplice Formation in the Ohře district has already been sketched by Kočí (2007).

\section{Geographical, geological, and stratigraphical setting, lithology and faunal content}

Late Turonian sediments of the NW part of the BCB represent a depositional complex with spatial and temporal alterations of the (nearshore) coarse-siliciclastic and the (offshore) carbonate predominated sedimentological sets. The nearshore siliciclastic sedimentation prevailing within the north-eastern part, gradually but relatively rapidly passes into the hemipelagial sedimentation in the south-east. Facial distribution and development of this depositional setting was, on one hand controlled by transgression/regression dynamics of a deltaic system situated on the southern seashore of the Western Sudetic Island (Laurin \& Uličný 2004) and, on the other hand, by the oscillation of marine bioproduction (Wiese et al. 2004). The conditions - relatively low terrestrial input and high bioproduction of calcareous nannoplankton - resulted in formation of a carbonatic platform in the studied areas of Ohře and Dresden districts, which were joined at the time of the Late Turonian sedimentation. Formation of this platform was accompanied by a relatively distinct cooling event (Wiese et al. 2004).

Úpohlavy quarry (Lafarge Cement Company) is situated in the north-western part of the Bohemian Cretaceous Basin (BCB). It provides an almost 30 meter high section (Fig. 2) through the Late Turonian sediments preserved in the tectonically sunken structure of the Ohře Ridge. The section thickness and the spatial extent of the outcrops make this quarry pivotal for any research on the Upper Turonian in that area and beyond.

The lithological set outcropping in the Úpohlavy quarry represents a typical hemipelagial succession of the Jizera and Teplice Formations. The exposed sediments of these formations can be subdivided into lithounits IX and Xa to Xc (Zahálka 1900) respectively. The overall geological and palaeontological characteristic of the locality is given only briefly herein as detailed descriptions have already been published by Čech et al. (1996) and Wiese et al. (2004). In general the section shows a multi-order rhythmical change of $\mathrm{CaCO}_{3}$ content (Laurin \& Uličný 2004), which is apparent from the base of the $\mathrm{Xb}$ unit upward. Beds are subhorizontal, slightly inclining to the west and tectonically dislocated by a couple of faults with relative subsidence reaching tens of centimetres. The only exception is a larger fault (SW-NE) situated near to the southern margin of the quarry and showing almost 20 meters of relative subsidence (Krutský 1972).

The lowermost part of the section consists of dark-grey marlstones of the lithounit IX which yield only a limited fauna with cancellothyrid brachiopods, oysters and shark teeth prevailing. There is no significant polychaete record for this unit in the Úpohlavy outcrops. The unit is cut off by an erosion surface and densely bioturbated at the top. Above this horizon a condensed layer with phosphatic clasts, frequent vertebrate remains and abundant coprolites - the so-called Lower Coprolite Bed - is developed. This is the lowermost part of the Teplice Formation (as well as of the Xa lithounit). This unit also did not yield any polychaete fossils. Marls of the upper part of Xa basal lithounit are overlain by the sharp-based limestone body of $\mathrm{Xb} \alpha$ (sensu Váně in Krutský et al. 1975), with more or less obvious condensation at the bottom ("Upper Coprolite Bed" sensu Wiese et al. 2004). A typical feature of this boundary is the presence of small to large (usually square decimetre but square metre scale in rare cases) subhorizontal accumulations of tiny fossils and shell debris with abundant brachiopod valves (Gyrosoria lata; for details see Sklenár \& Simon 2009). The limestones of $\mathrm{Xb} \alpha$ are relatively thick (more than $200 \mathrm{~cm}$ ) and rich in $\mathrm{CaCO}_{3}$ (77-89 wt\%) (Čech et al. 1996). In general the faunal content is not extensive and belongs - as well as that of the lower parts of the section - to the I. inaequivalvis / lamarcki stuemecki / cuvieri / perplexus inoceramid assemblage-zone or Subprionocyclus neptuni ammonite zone (Wiese et al. 2004). Typical are large nautiloids (Angulites, Eutrephoceras), ammonites (Lewesiceras) and small specimens of the echinoid Micraster leskei. Wood remains with teredolite burrows and Gastrochaena fossils are also common. The polychaete fauna is represented by soft-bottom dwellers building colonial reeflets as well as cryptic encrusters cemented to the internal surfaces of cephalopod shells and valves or to debris of large inoceramids. The overlying $\mathrm{Xb} \beta$ lithounit is characterised by a limestone/marlstone alternation and falls within the labiatoidiformis/striatoconcentricus inoceramid zone (S. neptuni ammonite zone). There is a diversified assemblage dominated by suspension-feeders, recognized at the base and in close proximity, represented in particular by rhynchonelliform brachiopods, sponges, bryozoans, bivalves (oysters, inoceramids and spondylids as well as endobenthic forms), and echinoids among the echinoderm representatives (see Wiese et al. 2004, Žítt \& Vodrážka 2008, Štorc \& Žítt 2008). The polychaete assemblage preserved in this layer is also remarkably rich, and represented particularly by encrusters cemented to shells and bioclasts (see Fig. 2).

A decrease in abundance, as well as diversity, noticeable already in the upper part of $\mathrm{Xb} \beta$ becomes far more obvious at the onset of the dark marls of unit $\mathrm{Xb} \gamma$ which represents the base of the Mytiloides scupini inoceramid zone. 
The fossil content of these beds, relatively poor in carbonate content (Wiese et al. 2004), consists of phosphatised inner casts of small endobenthic bivalves, tiny gastropods and rare brachiopods. Remains of neither serpulids nor sabellids are known from this unit.

The onset of unit $\mathrm{Xb} \delta$ shows a relative increase in carbonate content but this is not accompanied by any significant re-entry of the diversified oryctocenoses comparable to those of the $\mathrm{Xb} \beta$ unit. The fauna is still rather poor, represented by scattered large micrasterids, Spondylus spinosus, sponges and rare specimens of Gibbithyris semiglobosa. Only few specimens of encrusting worms (Neovermilia ampullacea; on benthic shells or loose) are known from this unit.

At the top of $\mathrm{Xb} \delta$, marked by two strongly bioeroded horizons and cut by a coarse-filled channel (Wiese et al. 2004), lies the topmost preserved unit of the quarry: lithounit Xc. Characteristic for this unit is an alternation of thicker beds of marls, poor in carbonate content, and thin layers of limestone with more or less common burrows (Planulites, Chondrites). The benthic community of this unit is poor, however about two meters above the base, a layer with a dwarfed benthic assemblage has been recently detected. This assemblage is dominated by tiny Plicatula nodosa accompanied by small spondylids, occasional oysters (Gryphaeostrea, Phygraea), rare dwarfish specimens of Spondylus spinosus, endobenthic bivalves represented by siphonal tubes only and brachiopods (Gibbithyris). Also rare ahermatypic corals (Parasmilia), remains of micrasteroid and cidaroid echinoids and ophiuroids were collected in and close to the horizon. Polychaetes are represented only by rare fragments of the sabellid Glomerula plexus.

\section{Material and methods}

The hitherto unstudied material had been collected by the private collector Michal Hulla between 1976-1981 and by Radek Vodrážka in 2002-2003; both collections were stored by the latter at the Czech Geological Survey, Prague (ČGS). The figured specimens were kindly donated to the National Museum, Prague (NM). A large proportion of the material was collected by one of the authors (T.K.) between 2003-2008 and during joint fieldwork with M.J. A large collection was obtained during fieldwork of National Museum between 2004-2008. All the specimens figured in the present paper are stored in the collections of this institution.

A certain amount of the material has been extracted using a new sulphuric-acid method (Vodrážka 2009). This technique proved to be very effective in extracting both sabellid and serpulid tubes from marly limestones without any adverse effect observed on the tube or its structure In

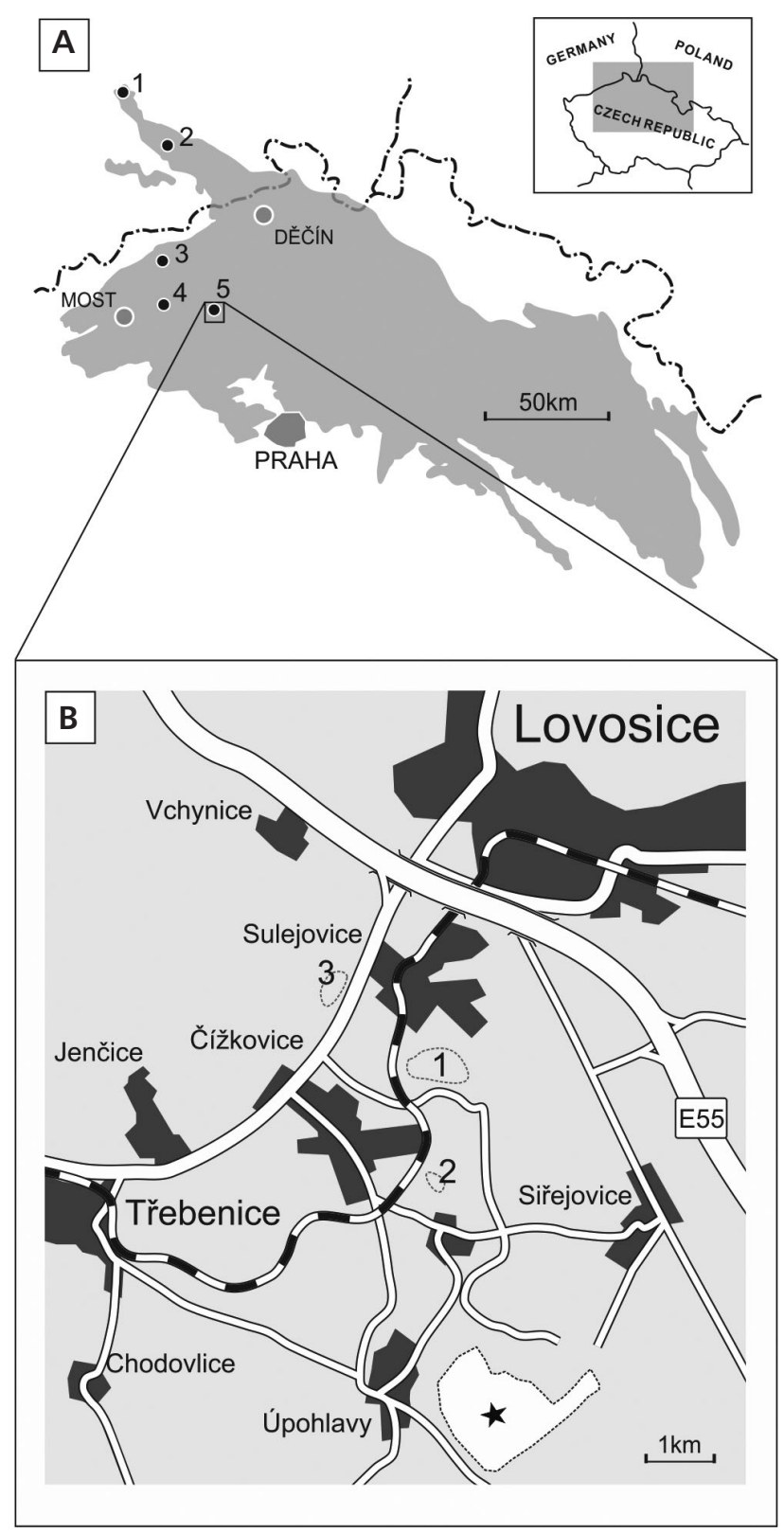

Figure 1. Geographical setting. - A - position of the Bohemian Cretaceous Basin, present-day distribution of its Late Cretaceous sediments (in grey), and localities mentioned in the text. 1 - Weinböhla, 2 - Strehlen, 3 - Hudcov, 4 - Kyselka, 5 - Čížkovice and Úpohlavy. Dash-and-dot line represents state borders. • B - position of the Úpohlavy quarry (asterisk) and former Čížkovice quarries (1-3).

addition, moistened solid potassium hydroxide was used for a more gentle, controlled method of preparation of one sample (Fig. 3E), where preservation of the taphonomic context was required. A greater number of specimens were cleaned by short exposure to ultrasonics and by more or less classical methods of mechanical preparation (needles, brushes, tiny chisels and pneumatic preparation tools). All the photographed specimens had been coated with ammonium chloride. 


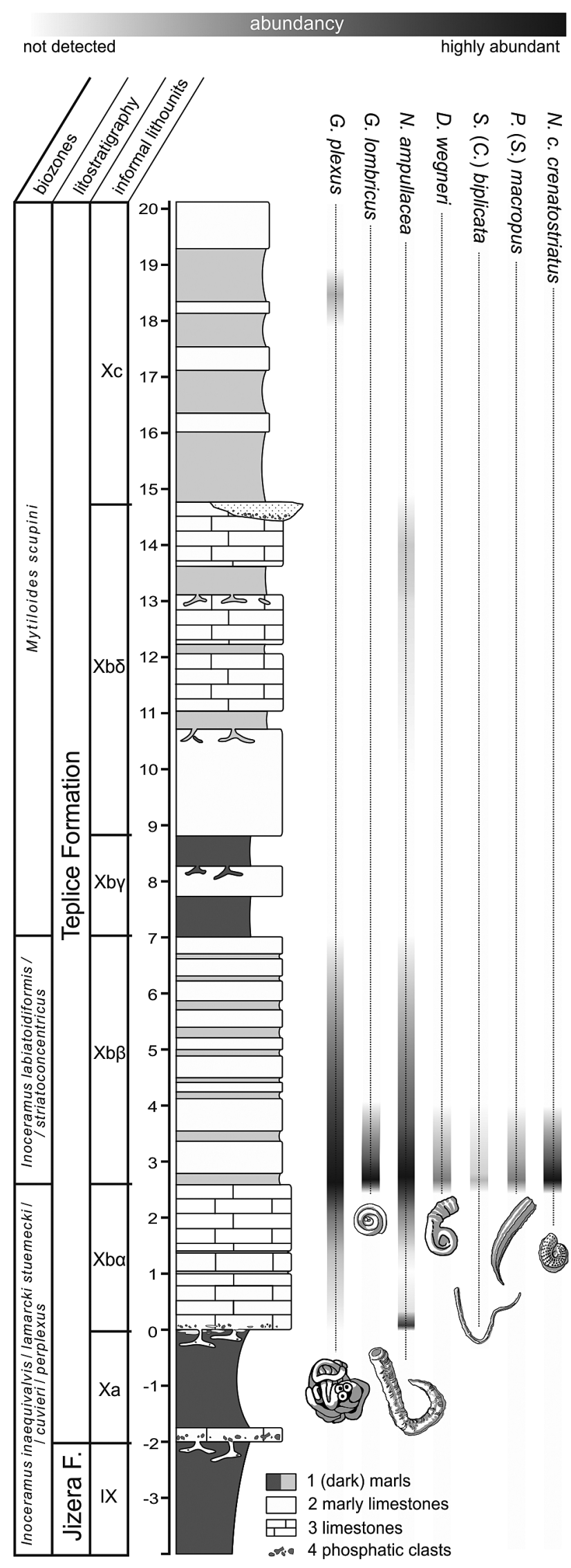

For analyses, an electron probe microanalyser Cameca SX100 and a fluorescence spectrometer Bruker Artax 400 were employed, both at the laboratories of the National Museum in Prague.

\section{Systematic palaeontology}

This systematic part is based on material from Úpohlavy quarry and provides revision of the species preserved in its oryctocenoses. Classification of sabellids and serpulids (including spirorbines) follows that of Regenhardt (1961), Ware (1975), Lommerzheim (1979), Jäger (1983, 1993, 2005), Ziegler (1984), Radwańska (1996), and Ten Hove \& Kupriyanova (2009). For the presented species we accept the synonymics published by Jäger (1983). The information presented below clarifies our understanding of species which have been reported from the respective areas.

Class Polychaeta Grube, 1850

Subclass Canalipalpata Rouse \& Fauchald, 1997

Ordo Sabellida Fauchald, 1977

Family Sabellidae Latreille, 1825

Subfamily Sabellinae Chamberlin, 1919

\section{Genus Glomerula Brünnich Nielsen, 1931}

Glomerula plexus (J. de C. Sowerby, 1829) Figures 3A-F, 5A, 6Fa

1829 Serpula Plexus J. de C. Sowerby; Sowerby, p. 201, pl. 598, fig. 1.

1883 Serpula gordialis Schlott. - Frič, p. 129.

1889 Serpula gordialis von Schlotheim [and] var. infibulata [and] var. implicata. - Frič, p. 96, fig. 122.

1893 Serpula gordialis Schlotheim, var. tuba Sowerby. Frič, p. 109.

1911 Serpula gordialis, var. serpentina. - Frič, p. 72, fig. 304.

1973 Glomerula gordialis (Schlotheim), 1820. - Ziegler, pp. 35 , 36, pl. 5, fig. 2 .

1983 Glomerula plexus (Sowerby, 1829). - Jäger, pp. 31-33, pl. 3, figs 1-3.

pars 1984 Filograna congesticia Regenhardt, 1961. - Ziegler, pp. 214, 215, pl. 1, fig. 1, non fig. 2.

Figure 2. Section through the Late Turonian sediments outcropping in the Úpohlavy quarry showing stratigraphical distribution of all sabellid and serpulid species reported here. Left hand column left to right: inoceramid biozones, litostratigraphical units, informal lithounits (used in accordance with Váně in Krutský et al. 1975). Scale given in meters. Adapted from Wiese et al. (2004). 
pars 1984 Glomerula gordialis (Schlotheim, 1820). - Ziegler, pp. 215, 216, pl. 1, fig. 5 , non figs 3,4 .

pars 1984 Glomerula solitaria Regenhardt, 1961. - Ziegler, pp. 217, 218, pl. 1, fig. 9, non fig. 8 .

non 1984 Sarcinella plexus (Sowerby, 1829). - Ziegler, p. 220, pl. 2 , fig. 6.

1984 Serpula prolifera Goldfuss, 1831. - Ziegler, pp. 223, 224 , pl. 3, fig. 3.

1996 Cycloserpula gordialis (Schlotheim, 1820). - Radwańska, pp. 66, 67, pl. 1, figs 1-4.

1996 Cycloserpula plexus (J. de C. Sowerby, 1829). - Radwańska, p. 67, pl. 1, figs 5-8.

2005 Glomerula plexus (J. de C. Sowerby, 1829). - Jäger, p. 131.

Material. - Altogether 52 specimens and many tube fragments. One specimen attached to a Sporadoscinia alcyonoides (Mantell) sponge (Fig. 3B) and two specimens attached to a Pyrospongia vrbaei Zahálka sponge, one to an indetermined pyritized sponge (Fig. 3A), and one to an echinoid test (Micraster leskei Desmoulins). Two specimens attached to oyster valves, and one specimen attached to an inoceramid ostracum. One specimen attached to the pedicle valve near the frontal commisure of a Woodwardirhynchia aff. cuneiformis (Pettitt) brachiopod (Fig. 5A). One coiled specimen with loose seeking tubes and attached oysters (Fig. 3E). 31 coiled, ball-shaped specimens not attached to any substrate. 10 fragments of straight or curved, non-coiled tubes not attached to any substrate and one fragment of two straight tubes attached to each other.

Description. - Tube diameter ranges between 1.2-3.8 mm (usually 1.6-3.0 mm). Specimens are solitary or gregarious. Often one to circa four tubes together forming an irregular sphaerical or elongated complex of 5.5-50 mm (usually $13-25 \mathrm{~mm}$ ) in maximal diameter. The straight or curved but non-coiled tube portions are up to $16 \mathrm{~mm}$ long in the frequently found loose fragments, but may reach about $60 \mathrm{~mm}$ in length in an exceptionally complete specimen (Fig. 3E). The tube surface is smooth, without any ornamentation and light brown in colour. Cross-section of the tube is circular to oval. A trilobate constriction of the lumen can be observed in some specimens (Fig. 3Cb). The aperture is simple.

Discussion. - The genus Glomerula ranges from the Hettangian to the Recent, and it is common and geographically widespread from the Upper Toarcian until the Eocene. After approximately one third of this very long time-span a new feature appears within the genus: it is a trilobate lumen in some of the tube sections (Jäger 1983, 1993, 2005). This seems to be true phylogenetic progress, presumably enabling the animal to fix itself inside its tube as protection against being drawn out of it by a predator.
The (facultative) presence of trilobate lumina can be used as a feature for taxonomic differentiation within the genus Glomerula (Jäger 2005). Jurassic specimens do not possess a trilobate lumen. From the uppermost Valanginian (new finds from Wąwal, Central Poland, kindly presented by Mariusz Salamon to M.J.) onwards trilobate lumina are present, but they are rare in most samples from the Lower Cretaceous and even in some samples from the Upper Cretaceous. Within the time-span reaching from the Lower Cretaceous to the Eocene, trilobate lumina may be present in Glomerula plexus (Sowerby), in Glomerula serpentina (Goldfuss) and in Glomerula lombricus (Defrance), but trilobate lumina are more frequent in $G$. serpentina than in G. lombricus.

The systematics of the genus Glomerula are problematic. The genus Glomerula consists of a large number of species, but it is nearly impossible to distinguish between them because the construction of the tube is so simple and the morphologic variation between specimens even within one sample is so wide. Therefore the scheme for the three aforementioned Cretaceous to Eocene "species" is certainly oversimplified and artificial. Of these three "species", G. lombricus (see next chapter) can easily be distinguished in offshore fine-grained limestone-marl and chalk facies by its small tube diameter.

More difficult is the discrimination between the two larger-sized "species". According to the scheme used by Jäger (2005), G. solitaria represents solitary tubes, whereas G. plexus represents clusters composed of more than one tube, often dozens or even hundreds in the characteristic large clusters occurring in the Santonian and Campanian of Northern Germany, England (type area) and Southern Sweden. However, at many localities, including Úpohlavy, often only two, three or four tubes are connected to each other. Formally, these small clusters would have beeen named "G. plexus", but in reality they probably represent only dense populations of the common solitary "species" G. serpentina. Moreover, in practice it is often difficult to decide if a Glomerula knot is composed of one or two tubes without preparation or section. Therefore, in contrast to Jäger (2005), we decided to combine all Glomerula specimens from Úpohlavy with a large tube diameter into one single species, regardless of they are solitary or composed of several tubes. This collective species is named G. plexus, because the name plexus has priority over the name serpentina.

Compared to the cluster of the type specimen of G. plexus and to other large clusters from the type area, the specimens from Úpohlavy differ (1) by the relatively low number of tubes within a cluster, (2) by their relatively large tube diameter (up to $3 \mathrm{~mm}$ or more at Úpohlavy, but only circa $1 \mathrm{~mm}$ in the type specimen), and (3) by their mostly more or less isodiametrical shape instead of bundle-like shape. Nevertheless, we regard them as conspecific. 
Glomerula lombricus (Defrance, 1827) Figure 3G, H

1827 Serpula? lombricus Defrance. - Defrance, p. 571. pars 1983 Glomerula gordialis (Schlotheim, 1820). - Jäger, pp. 26-31, pl. 2, figs 11, 12, non figs 1-10, 13-18.

pars 1984 Glomerula gordialis (Schlotheim, 1820). - Ziegler, pp. 215, 216, pl. 1, figs 3, 4, non fig. 5.

1984 Glomerula scitula Regenhardt, 1961. - Ziegler, p. 217 , pl. 1, fig. 7 .

pars 1984 Glomerula solitaria Regenhardt, 1961. - Ziegler, pp. 217,218 , pl. 1, fig. 8 , non fig. 9 .

1984 Spiraserpula subinvoluta (Reuss, 1845). - Ziegler, p. 226, pl. 3, fig. 8 .

non 1993 Cycloserpula lombricus (Defrance, 1827). - Jäger, pp. 76-78, pl. 1, figs 1-20.

2005 Glomerula lombricus (Defrance, 1827). - Jäger, pp. 130, 131, pl. 1, figs 2-10.

Material. - Altogether 52 specimens. One specimen attached to a large bryozoan colony. Another specimen is fixed to a serpulid tube, Neovermilia ampullacea. Four specimens are of subplanispiral form, 43 specimens are of coiled-ball form, and three short straight or curved, noncoiled tube fragments, all not attached to any substrate.

Description. - Presumably all specimens consist of single tubes, although it cannot be excluded that some specimens may be composed of more than one tube. The tubes are very small. Tube diameter varies between $0.4-1.0 \mathrm{~mm}$ (usually $0.5-0.9 \mathrm{~mm}$ ). A few coiled-balls of $1.2-1.3 \mathrm{~mm}$ tube diameter are determined as G. plexus here for the sake of continuity in discrimination features, even though their other features fall within the rank of G. lombricus. In specimens of the planispiral form the tube diameter is smaller on average than in the coiled-ball forms. The greatest diameter of coiled-balls reaches up to 2.2-6.5 mm (usually $2.7-4.8 \mathrm{~mm}$ ). The tube surface is smooth, without any ornamentation and light brown in colour. Cross-section is circular. In contrast to G. plexus, no trilobate constriction of the lumen has been observed within the specimens of G. lombricus from Úpohlavy. The aperture is simple.
Discussion. - Distinguishing between G. lombricus and the similar but larger Glomerula species seems reasonable in chalk facies and in offshore limestone/marl facies, because specimens of intermediate tube diameter are relatively rare (Jäger 1983, 2005). In those facies, all solitary Glomerula specimens with a tube diameter less than $\mathrm{ca} 1 \mathrm{~mm}$ are determined as G. lombricus. A similar situation is found to be present in the material described here from the Úpohlavy quarry. The principle mistake that some juvenile specimens of the large-sized species are erroneously determined as members of the small-sized species must be tolerated.

In contrast, Glomerula material collected from coarsegrained facies and/or nearshore sites shows a unimodal size range from small to large in tube diameter frequency and therefore is presumed to represent one single species. A good example is provided by a collection of about one thousand specimens gained from debris of Lower Turonian siltstones at the nearshore locality of Velim (Kolín district). The lumen-diameter of these tubes includes sizes from small, medium ( $c$ a $1-1.8 \mathrm{~mm}$ ) to large in a unimodal distribution. Because this single species is able to reach a large size, it seems more logical to combine it taxonomically with the large rather than the small species from the offshore realm (see above), even though at some nearshore sites, large specimens may be relatively rare. Therefore, as already stated by Jäger (2005), it would have been more logical if Jäger (1993) had named the specimens from the Danian Geulhem Member of the Maastricht-Aachen-Liège area $G$. serpentina instead of lombricus, even though the diameter of the tubes is on average only $0.7-1.3 \mathrm{~mm}$, with the maximum of $1.8 \mathrm{~mm}$ only rarely recorded.

Family Serpulidae Rafinesque, 1815

Subfamily Serpulinae Rafinesque, 1815

\section{Genus Neovermilia Day, 1961}

Neovermilia ampullacea (J. de C. Sowerby, 1829)

Figures 4A-E, 5B-F, 6B

1829 Serpula ampullacea J. de C. Sowerby. - Sowerby, p. 199 , pl. 597 , figs $1-5$.

Figure 3. Sabellid polychaetes, Úpohlavy quarry. - A - Glomerula plexus (Sowerby) irregularly coiled tube attached to an indeterminate partially pyritized sponge. a - general view, b - detailed view; NM-O6937. • B - Glomerula plexus attached to a sponge Sporadoscinia alcyonoides (Mantell); NM-O6938. - C - bundle of Glomerula plexus; a - general view showing three large lumina, circular in cross-section, b - detailed view of tubes in another cross-section, note the trilobate lumen of the uppermost; NM-O6939. - D - Glomerula plexus, detailed view showing heterogeneous material (Neoflabellina sp.; undeterminable shell fragment) tangled in the bundle; NM-O6940. • E - Glomerula plexus, specimen showing somewhat loose bundle (Ia) and "seeking" tubes (Ib). One of the three specimens (II) of Gryphaeostrea canaliculata is directly attached to the reeflet; the latter are loosly associated with it. Fragment of a branched bryozoan colony cf. Desmepora sp. (III) and spine of phymosomatid echinoid (IV) lacking any close relationship to the worm reeflet; NM-O6941. $\bullet \mathrm{F}$ - a small glomerulate knot of Glomerula plexus exhibiting change in tube-growth pattern during ontogeny: chaotic tangle and an ascending(?) helically coiled portion; NM-O6963. $\bullet \mathrm{G}, \mathrm{H}-$ two flat subplanispiral specimens of Glomerula lombricus (Defrance). A large benthic foram, is visible from the middle to the right of the spiral shown at Hb; NM-O6961 (G), NM-O6962 (H). 

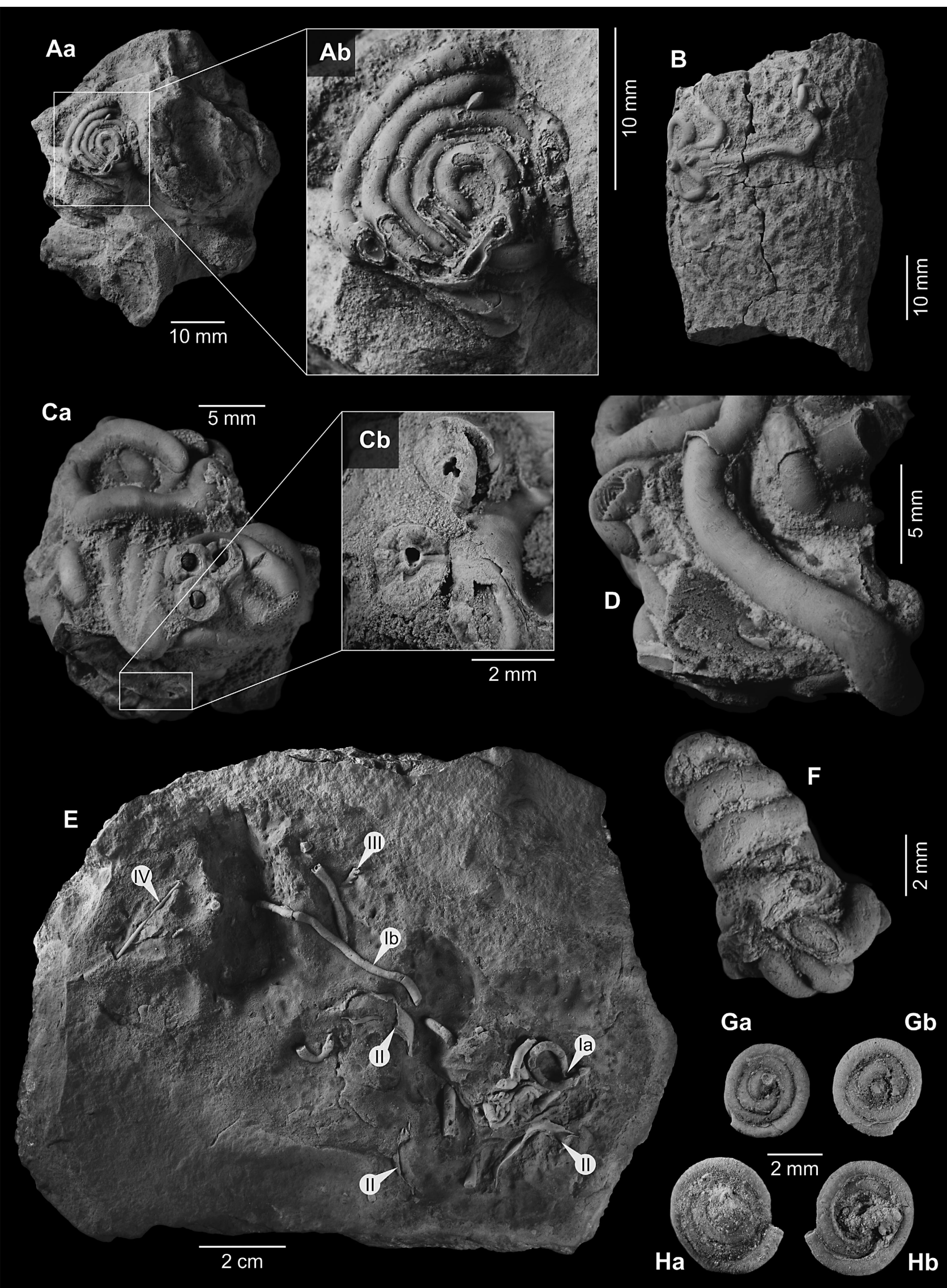
non 1883 Serpula ampulacea [sic!] Sowerby. - Frič, p. 128, fig. 114a, b.

? 1883 Serpula macropus Sowerby. - Frič, pp. 128, 129, fig. $115 \mathrm{a}, \mathrm{b}$.

?1889 Serpula macropus Sowerby. - Frič, p. 96.

1889 Serpula pustulosa Geinitz. - Frič, p. 96.

1889 Serpula ampullacea Sowerby. - Frič, p. 97.

?1911 Serpula ampulacea [sic!] Sowerby. - Frič, p. 72, fig. 305.

?1973 Serpula ampullacea Sowerby, 1829. - Ziegler, pp. 38, 39, pl. 6, fig. 3.

?1974 Serpula ampullacea Sowerby, 1829. - Ziegler, pp. 61-64, figs 1-4.

?1978 Pomatoceros trachinus (Goldfuss). - Ziegler, pp. 217, 218, figs 1.1 and 2.1 .

?1978 Pomatoceros lophiodus (Goldfuss). - Ziegler, p. 218, figs 1.2 and 2.2 .

1983 Proliserpula ampullacea (Sowerby, 1829). - Jäger, pp. 41-45, pl. 5, figs $1-8$.

1984 Glomerula nuntia nov. sp. - Ziegler, pp. 216, 217, pl. 1 , fig. 6.

1984 Serpula antiguata [sic!] Sowerby, 1829. - Ziegler, p. 222 , pl. 3, fig. 1 .

?1984 Pomatoceros trachinus (Goldfuss), 1833. - Ziegler, p. 232, pl. 4, fig. 10.

?1984 Pomatoceros triangularis (Münster), 1831. - Ziegler, pp. 232, 233, pl. 4, fig. 11.

1984 Proliserpula ampullacea (Sowerby), 1829. - Ziegler, p. 233, pl. 5, figs $1,2$.

1984 Proliserpula ornata nov. sp. - Ziegler, pp. 233, 234, pl. 5 , fig. 3.

1984 Vepreculina soukupi nov. sp. - Ziegler, pp. 236, 237, pl. 6, fig. 3.

1991 Proliserpula ampullacea (Sowerby 1829). - Jäger, p. 143, pl. 1, figs 2-5; pl. 2, fig. 10.

1996 Proliserpula tumida Regenhardt. - Marcinowski, pl. 19, figs 1, 5-7.

1996 Proliserpula ampullacea (J. de C. Sowerby, 1829). Radwańska, pp. 67, 68, pl. 2, figs 3-10; pl. 12, fig. 4.

2005 Neovermilia ampullacea (J. de C. Sowerby, 1829). Jäger, p. 154, pl. 6, figs 4-6.
2007 Proliserpula tumida Regenhardt. - Olszewska-Nejbert, pl. 32, figs 7, 8, 10.

Material. - Altogether 79 tubes. 12 tubes attached to the ostracum of inoceramid valves (up to three tubes on one valve), at least 8 tubes attached to oyster valves, one tube attached to a sponge, 1 specimen attached to the skeleton of an octocoral (Moltkia?) (Fig. 6B), one specimen fixed to a Micraster leskei Desmoulins echinoid test. Four juvenile specimens attached to individual adult tubes. The majority of specimens are fragments of the attached tube portion which may originally have settled upon the periostracum of inoceramids and other bivalves but later fell off. In addition to the aforementioned number of tubes, a larger number of specimens (about 50) were recorded on their attachment surfaces in internal moulds of nautiloid and ammonoid shells (see palaeoecological remarks). At least 18 specimens are fragments of the free tube portion. Circa 10 per cent of the specimens are infested by the symbiont Protulophila gestroi Rovereto. A similar hydroid infestation has already been described from an undetermined serpulid tube from the coastal facies of the Bohemian Cretaceous Basin by Zágoršek et al. (2009).

Description. - Most tubes are attached to the substrate by their longest part, they are straight or somewhat curved and subtriangular to rounded in cross-section, thus resembling the genus Spirobranchus. If space was limited, for example if the substrate was of only moderate size or if several tubes settled upon a single substrate, for example 6 tubes on a single oyster shell (Fig. 5B), the attached tube portion is strongly curved and tends to form an irregular loop. The free tube portion is straight or slightly curved, sometimes steeply erect, but in most specimens more or less continuing the growth direction of the fixed tube portion, or only slightly erect. The tube diameter may reach up to $6 \mathrm{~mm}$, but in most specimens it ranges between 3 and $5 \mathrm{~mm}$. In most specimens there is a longitudinal keel present on the fixed tube portion, the ratio of specimens with a keel versus specimens without a keel is about 2 to 1 . The keel may be delicate in some specimens (Fig. 5C) but tall and strong in others, straight (Fig. 5E) or, more often, undulating (Fig. 5D).

Figure 4. Serpulids of genera Neovermilia and Neomicrorbis, Úpohlavy quarry. • A - detail of a natural inner mould of a nautiloid shell (Eutrephoceras sp.) bearing polychaete encrusters. Neomicrorbis sp. (Ia) and Neovermilia ampullacea (Sowerby) (Ib) represent the skeletozoan group of epibionts attached to the inner surface of the bodychamber (observable as imprints of their upper side). Neomicrorbis c. crenatostriatus (Münster in Goldfuss) (II) solely represents the second group of epibionts (seen from above, shell preserved); NM-O6964. • B - Neovermilia ampullacea (Sowerby) attached to a fragment of shell prism of Inoceramus hercules (Heinz, 1928); NM-O6942. $\bullet \mathrm{C}$ - another tube of Neovermilia ampullacea growing over the edge of a broken ostracum of an inoceramid valve (I. hercules); a - adoral tube portion, $\mathrm{b}$ - portion attached to edge of fracture, $\mathrm{c}$ - aboral tube portion, note mature bryozoan (Plagioecia sp., see Sklenár \& Zágoršek 2012) colonies right of the tube, d - detail showing growth disturbance probably documenting change of substrate position; NM-O6943. • D - internal mould of a nautiloid with remains of serpulid tubes (Neovermilia ampullacea), oysters (Pycnodonte vesicularis Lam.) and cyclostomate bryozoans (all exposed from below); a - general view; b, $\mathrm{c}$ - details. Note vesicular wall structure apparent at the attachment areas; NM-O6944. E - Neovermilia ampullacea attachment area of several specimens exhibited from below, internal serpulid epibionts preserved in inner mould of an ammonoid shell (Lewesiceras sp.); NM-O6945. 

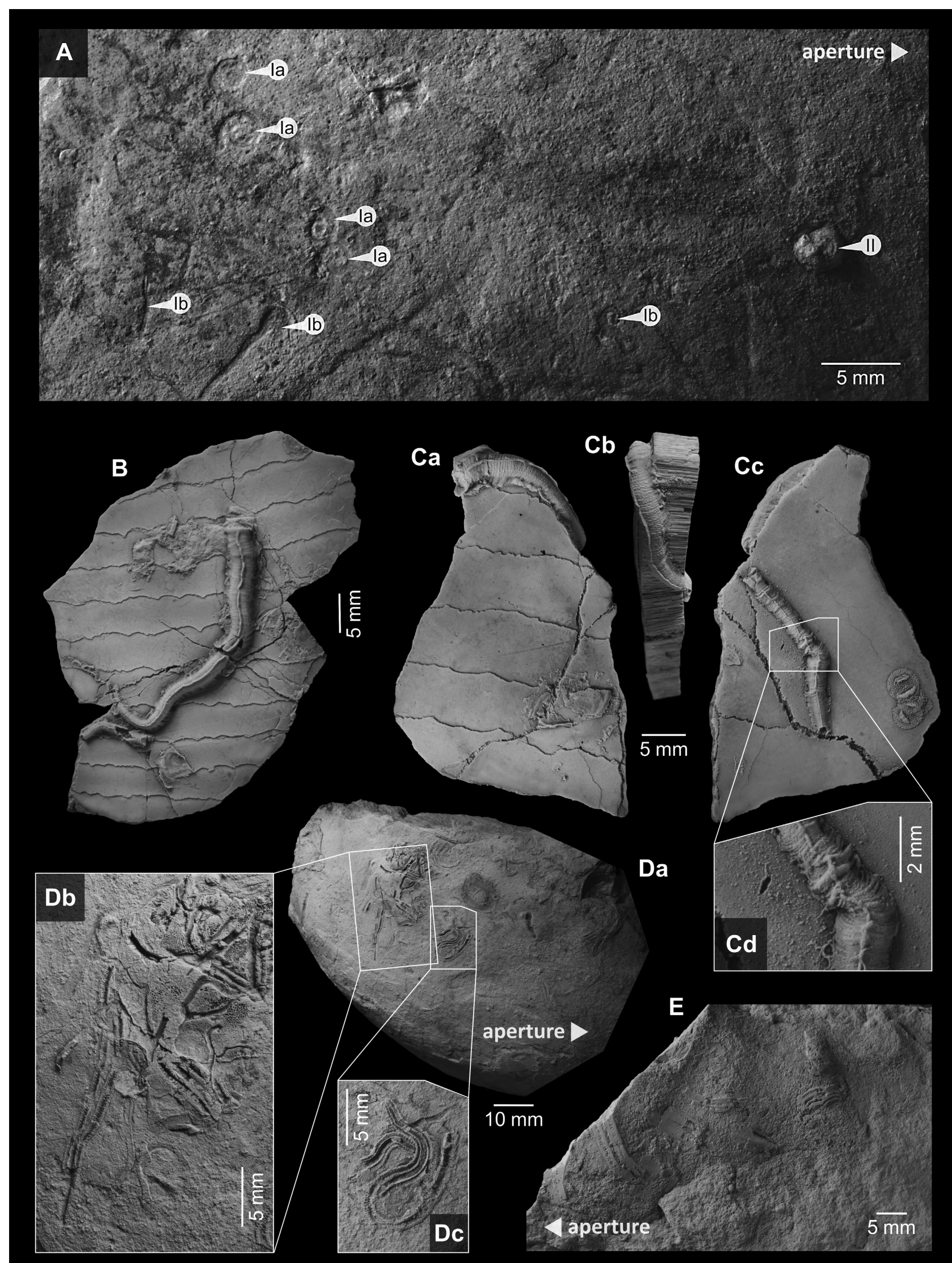
In the free tube portion, the ratio of specimens with a keel versus specimens without a keel is about 3 to 2 . Either in the fixed or free tube portion, there is a general tendency for the keel to become weaker and/or vanish in the anterior direction. The tubes may or may not bear distinct annular peristomes. Usually delicate transversal ornamentation is present in the shape of very fine, sometimes indistinct corrugations or pustulae (Fig. 5C-F). The tube wall is thin to moderate in most specimens but may be even very thick in some others, the lumen is circular. Usually a basal cellular layer is strongly developed and distinct (e.g. Fig. 4D).

Discussion. - The genus Neovermilia first occurred in the Upper Oxfordian (Radwańska 1996). The complex of Neovermilia ex gr. ampullacea is very variable in tube crosssection (circular, subtriangular, triangular), and in the ornamentation (annular/ampullacean peristomes present or absent, fine transversal ornamentation present or absent, keel present or absent, keel fine or tall, straight or undulating). Also the tube wall shows remarkable variation being usually thin but relatively thick in some specimens. The base of the tube often bears alveolar chambers, but shorter than in Spirobranchus and Pyrgopolon.

This structure is an obvious feature of serpulid attachment areas observed in some internal moulds of ammonoid and nautiloid cephalopods (Lewesiceras; Eutrephoceras, Angulithes) from Úpohlavy (Fig. 4D, E). The rest of the tube cannot be observed, but the distinct alveolar chambers and the slow to moderate growth in tube width allow us to consider them $N$. ampullacea: the single, frequent species with both the features found in the respective area. Nevertheless, there are more serpulid lineages possessing alveolar chambers and the alveolar chambers alone are not inherent even in the majority of living Neovermilia species (H.A. ten Hove, personal communication).

Previously Neovermilia ampullacea had been attributed to the genus Proliserpula Regenhardt, 1961. According to Jäger (2005) Proliserpula is a subjective synonym of Neovermilia. Shape and structure of the tube of the PlioPleistocene to Recent species Neovermilia falcigera (Roule) (see Zibrowius \& Ten Hove 1987, fig. 2) is very similar in the shape and outer aspect of the tube to the Cretaceous specimens without a keel.

Geinitz (1875) discriminated between ampullacea lacking a keel and several species possessing a keel, i.e. laevis, trachinus, pustulosa and "macropus". In spite of our efforts, we failed to sort the material into such a number of different morphotypes. In our opinion, all these with the exception of laevis, fall within N. ampullacea (Sowerby). Neovermilia ampullacea (Sowerby) resembles Neovermilia avita (Sowerby) which occurs in the Lower Turonian of England and Neovermilia obtusa (Sowerby) which occurs in the Coniacian to Santonian of England (Norfolk, Kent, Sussex). N. avita differs in tube diameter reaching only 1-3 mm, much smaller than in $N$. ampullacea, whereas $N$. obtusa is $3-5 \mathrm{~mm}$ in diameter and thus only slightly smaller than $N$. ampullacea.

When discussing the genus Propomatoceros, Ware (1975) also mentioned Serpula triangularis Goldfuss, S. biplicata Reuss, and S. avita Sowerby. According to Jäger (1983), Serpula triangularis belongs to Neovermilia ampullacea, and Jäger (2005) considered S. avita to be a subspecies of N. ampullacea. Serpula obtusa Sowerby is also closely related to or conspecific with $N$. ampullacea.

Serpula macropus (Sowerby) mentioned by Frič (1889) and figured by Geinitz (1875, pl. 37, figs 10-12) belongs to N. ampullacea, because Pyrgopolon (Septenaria) macropus (Sowerby) differs from Geinitz's figures 10-12 in three features: (1) different tube structure at the base of the fixed tube portion, (2) more rapid growth widthwise, (3) lack of peristomes in normal development. Regenhardt (1961, pl. 2, fig. 6) refigured Geinitz's specimen from pl. 37, fig. 12 and erected a new name, Proliserpula (Proliserpula) tumida Regenhardt. In our opinion, tumida also belongs to $N$. ampullacea.

Proliserpula tumida Regenhardt mentioned by Marcinowski et al. (1996, pl. 19, figs 1, 5-7) and Olszewska-Nejbert (2007, pl. 32, figs 7, 8, 10) from the Upper Turonian-Coniacian of Besakty (Mangyshlak Mountains at western Kazakhstan) belongs to N. ampullacea.

As already stated by Lommerzheim (1979, p. 152), the "Serpula pustulosa" specimen figured by Geinitz (1875,

Figure 5. Tubes of polychaetes of genera Glomerula and Neovermilia, Úpohlavy quarry. • A - Glomerula plexus (Sowerby) attached to the pedicle valve close to the frontal commisure of the brachiopod Woodwardirhynchia aff. cuneiformis (Pettitt). Position of the tube leads to an assumption of epizoozoantic mode of life for the sabellid individual and supports the hypothesis of life habit in Cretaceous rhynchonellids of this morphology ( $e . g$. Simon 1998); NM-O6869. • B - several specimens of Neovermilia ampullacea (Sowerby) attached to an oyster valve, a clear preference for the outer surface is noticeable; $\mathrm{a}$ - top view, $\mathrm{b}$ - lateral view; NM-O6867. $\bullet \mathrm{C}$ - anterior tube portion of Neovermilia ampullacea (Sowerby) with keel poorly developed and very faint; fading, wavelike to pustulose, transversally orientated ornamentation; $\mathrm{a}$ - aperture, $\mathrm{b}$ - upper side, c - lateral view; NM-O6951. • D - anterior tube portion of Neovermilia ampullacea (Sowerby) with a tall but thin, undulating keel and transversally distributed remarkable pustulose to corrugate ornamentation reaching the sides of the keel; $\mathrm{a}$ - ampullacean aperture, $\mathrm{b}$ - upper side, $\mathrm{c}$ - lateral view showing buttresses protruding from the tube wall close to the adoral end of the fragment; NM-O6952. E - anterior tube portion of Neovermilia ampullacea (Sowerby) with a tall, strong, only slightly undulating keel, pustulose to corrugate transversal linear ornamentation; a - aperture, b-upper side, c - lateral view. Note the attachment area protruding behind the apertural plane; NM-O6953. - F - tube fragment of Neovermilia ampullacea (Sowerby) with a strong, undulating keel and very distinct transversal ornamentation; $\mathrm{a}$ - upper side, $\mathrm{b}$ - lateral view; NM-O6954. 


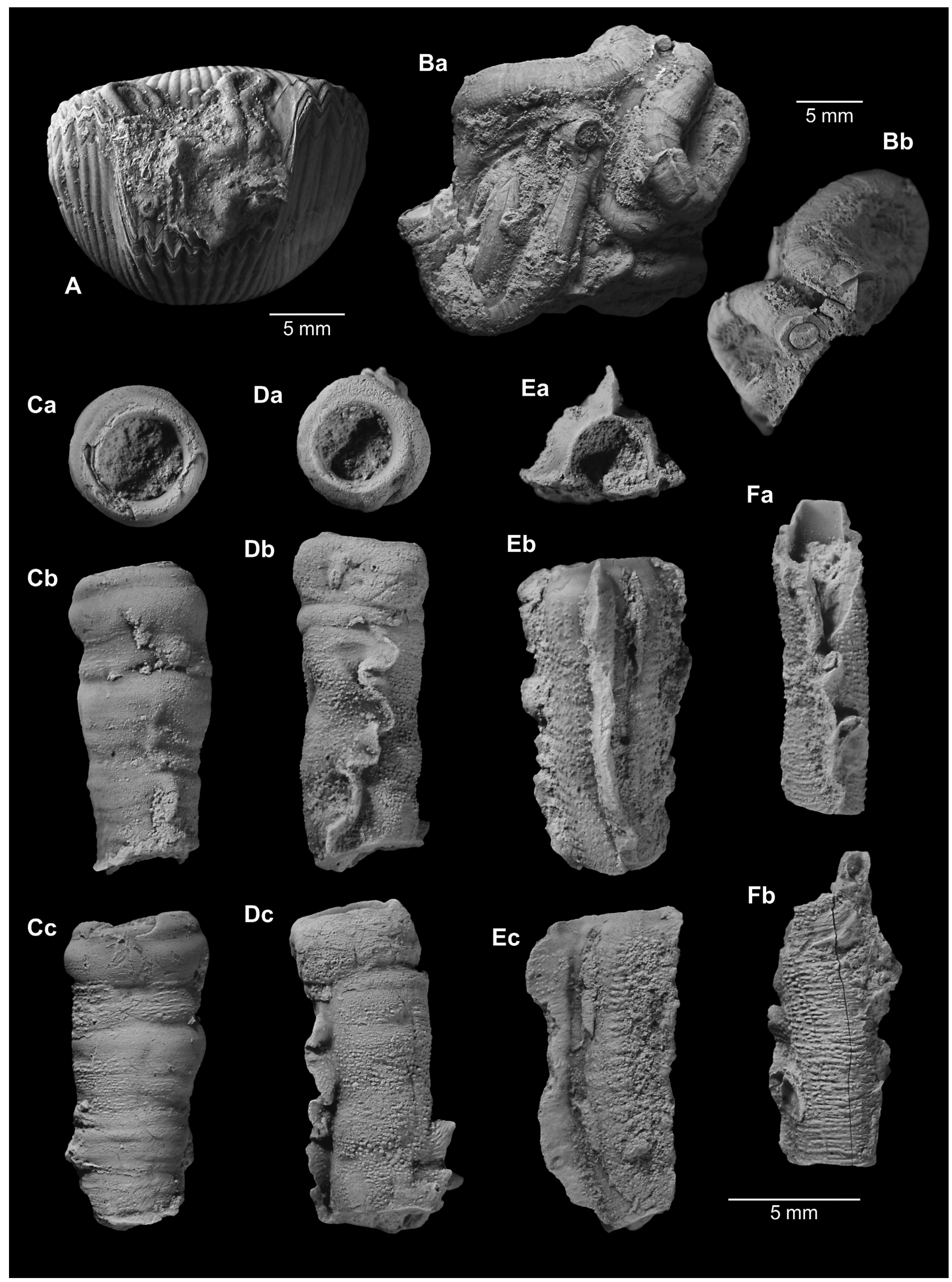


pl. 37, fig. 5) and refigured by Regenhardt (1961, text-fig. 2) is infested by the symbiont Protulophila.

N. hemmoorensis (Jäger, 1983) from the Maastrichtian of Hemmoor is distinguished by three fine, granulated and distinct longitudinal keels and by very strongly developed but short annular peristomes.

\section{Genus Dorsoserpula Parsch, 1956}

\section{Dorsoserpula wegneri (Jäger, 1983)}

Figure 6A

?1889 Serpula rotula, Goldfuss. - Frič, p. 97.

1983 Parsimonia wegneri nom. nov. - Jäger, pp. 38, 39, pl. 4, figs 1-9.

pars 1984 Sarcinella minor nov. sp. - Ziegler, pp. 220, 221, pl. 2, fig. 4 , non fig. 5 .

1984 Martina parva nov. sp. - Ziegler, pp. 227, 228, pl. 3, fig. 9.

1984 Spirorbis asper (von Hagenow), 1840. - Ziegler, p. 242, pl. 7, fig. 6 .

1984 Spirorbis subrugosus (Münster), 1831. - Ziegler, p. 244 , pl. 8 , fig. 2.

1984 Spirorbis superminor nov. sp. - Ziegler, pp. 244, 245, pl. 8 , fig. 3.

2005 Dorsoserpula wegneri wegneri (Jäger, 1983). Jäger, p. 163, pl. 4, figs 3-6.

Material. - Altogether 9 specimens. Four planispirals, one of them (Fig. 6A) coiled completley around a Bourgueticrinus crinoid columnal, and one formerly coiled around a no longer preserved cylindrical substrate. One fragment of a planispiral tube attached to a Spondylus valve. Four fragments of non-spiral tube portions showing no trace of any substrate.

Description. - In nearly half the number of specimens, the tube is almost planispirally coiled, in the most typical specimens completely around a cylindrical object which must have stood in an upright position, for example a crinoid stem. Usually the spiral consists of only one to two whorls.
Other, less typical tubes may show an irregular growth form. In some specimens, the spiral is followed by a free, more or less straight or slightly curved tube portion. This may be erected more or less obliquely above the plain of the spiral (Fig. 6A). The spiral ranges from 7.5-14.9 $\mathrm{mm}$ in diameter, in spiral specimens the tube diameter varies between $2.7-4.1 \mathrm{~mm}$ and the diameter of the lumen between 2.0-3.5 mm, in non-spiral tube fragments the tube diameter is $2.5-6.0 \mathrm{~mm}$. In spiral specimens, the anteriormost free tube portion may be more than $4 \mathrm{~mm}$ long, and the nonspiral tube fragments are up to $13 \mathrm{~mm}$ long. The tube and lumen cross-sections are circular.

The "additional tube" ("Nebenröhre" of Jäger 1983, 2005 ) is developed only indistinctly and only in one of the spiral tubes and in one or two of the non-spiral tube fragments. The incremental lines and the weak to moderately strong peristomes are spaced irregularly and are somewhat curved forward at the median line which in the typical spiral tubes coiling around a cylindrical substrate is situated at the periphery of the spiral. In this region is a narrow furrow developed in the spiral tube portion. Near the anterior end of the spiral, this furrow may either turn into a rounded and sometimes somewhat undulating keel which later disappears in the anteriormost free tube portion, or the furrow may disappear directly without any intermediate keel. In the anteriormost free tube portion, there may be a furrow on one of the two latera and another furrow on the underside. The tube's surface is relatively smooth, except for the keel, furrows, peristomes, and "additional tube". The tube wall is thick to moderate in most specimens, but thin in a few specimens. The tube is usually bright orange brown, but may be darker brown without any orange in some specimens.

Discussion. - While determination of the vast majority of specimens is unambiguous, different opinions about affiliation to either Dorsoserpula wegneri or Neovermilia ampullacea may exist in a few specimens lacking distinctive features.

One of the main distinctive features is the "additional tube" ("Nebenröhre"). This characteristic feature of the genus Dorsoserpula is present in only two or three specimens

Figure 6. Polychaete tubes, Úpohlavy quarry. • A - Dorsoserpula wegneri (Jäger), tube coiling around a columnal of a crinoid Bourgueticrinus sp.; $\mathrm{a}$ - bottom view, b - top view; NM-O6868. $\bullet \mathrm{B}$ - Neovermilia ampullacea (Sowerby), tube attached to octocoral bases overgrowing unpreserved plant (?) substrate; $\mathrm{a}$ - view of one of the sample's ends showing shape of the coral substrate and the tube laterally, b - general view showing the serpulid tube; NM-O6824. • C - Pyrgopolon (Septenaria) macropus (Sowerby), anterior tube portion; a - pentagonal aperture, b - top view showing keel, c - lateral view; NM-O6955. - D - Serpula? (Cementula?) biplicata (Reuss), tube attached to a fragment of an inoceramid valve; a - general view, b-detailed view showing the tube with a distinct keel; NM-O6866. - E - collapsed test of echinoid Micraster leskei (Desmoulins) with twelve tubes of Neomicrorbis $c$. crenatostriatus (Münster in Goldfuss) attached to the visible surface. Seven well-built tubes and five juvenile ones; a - general view, b - detailed view showing three well-built tubes with remarkable ornamentation; NM-O6865. • F - Glomerula plexus (Sowerby) and a dextrally coiled tube of Neomicrorbis c. crenatostriatus attached to an outer surface of an oyster valve; a - general view, b - detail showing lateral view of $N$. c. crenatostriatus; NM-O6949. • G - Neomicrorbis c. crenatostriatus, sinistrally coiled tube attached to a fragment of an inoceramid-valve ostracum; a - general view, $\mathrm{b}$ - detail showing the tube; NM-O6950. 


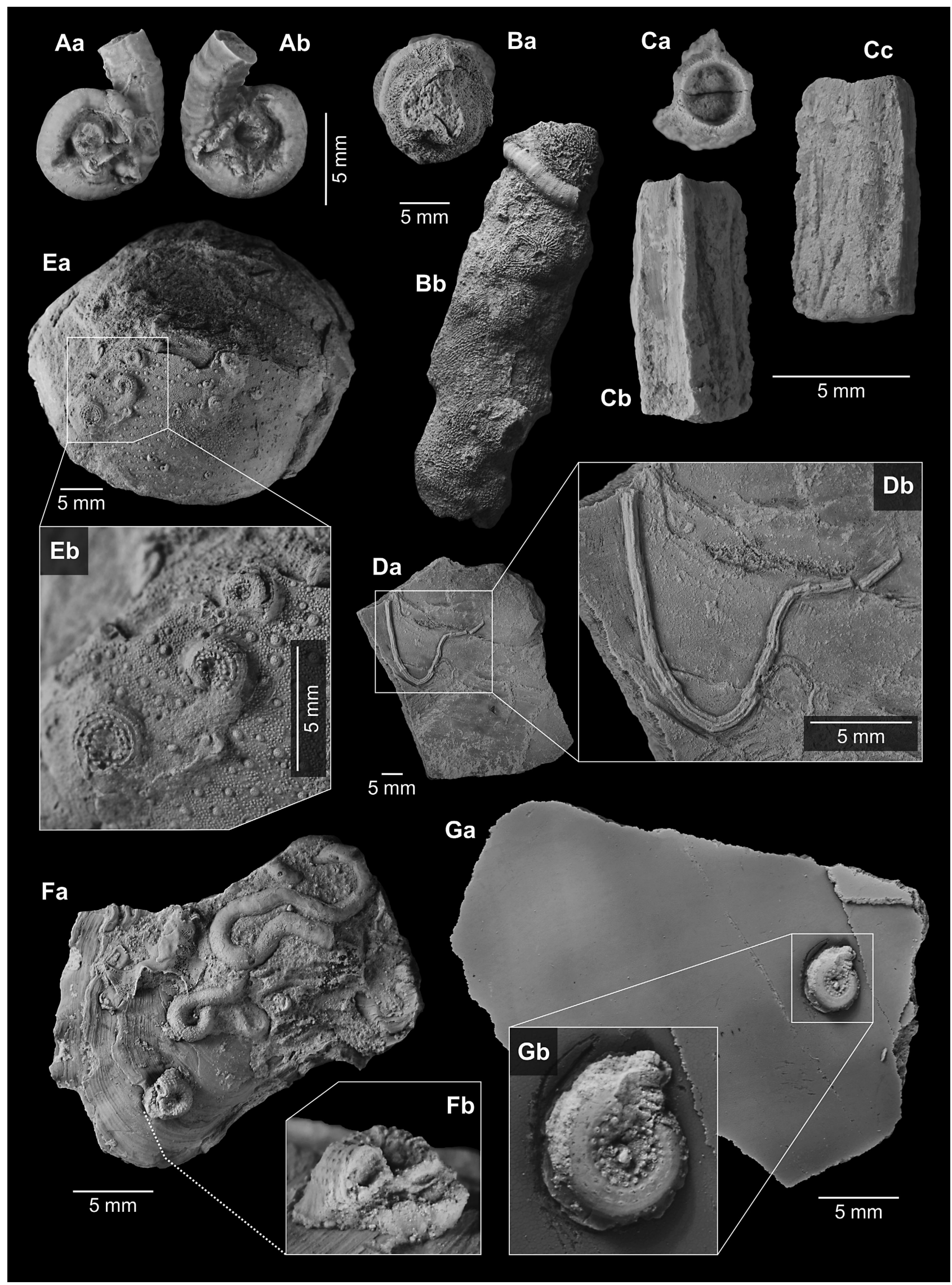


from Úpohlavy and, unfortunately, less distinctly developed in these specimens. From Dresden-Strehlen, specimens possessing a typically developed "additional tube" are known. In general, in all other localities the "additional tube" is developed only in some of the Dorsoserpula specimens.

The second best identification feature of Dorsoserpula, coiling spirally around an upright cylindrical substrate, is seen in two spirals from Úpohlavy. In contrast, Neovermilia ampullacea, either coiled spirally or not, is usually fixed to a more or less plain or uneven surface, and therefore the geometry of these two types of spiral is considerably different. However, also in other localites, non-coiled, less typical Dorsoserpula specimens occur. And vice versa, in very rare cases Neovermilia ampullacea may also coil around an upright cylindrical substrate.

The third best distinctive feature is the (microscopic) surface of the tube which is usually rather smooth (except for the keel, furrows, peristomes, and additional tube) in Dorsoserpula but usually shows delicate granula and (microscopic) crests in N. ampullacea. However, exceptions exist in both directions: $N$. ampullacea may often be relatively smooth, and Dorsoserpula may rarely show granula and crests.

Two more discriminating features are even less reliable because exceptions in both directions are even more common. Only statistically, the tube wall is thicker in Dorsoserpula than in N. ampullacea, and also only statistically, the colour of Dorsoserpula is somewhat brighter and orange brown compared to the somewhat darker brown with less orange in N. ampullacea.

As stated by Jäger (2005), the species Sarcinella minor, Martina parva, and Spirorbis superminor described by Ziegler (1984) all belong to Dorsoserpula wegneri. The holotype piece of Sarcinella minor consists of two small D. wegneri tubes attached to a cidaroid spine.

Genus Serpula Linnaeus, 1758?

Subgenus Serpula (Cementula) Regenhardt, 1961?

\section{Serpula? (Cementula?) biplicata (Reuss, 1845)}

Figure 6D

1845 Serpula biplicata Reuss. - Reuss, p. 18, pl. 5, fig. 23a, b. 1889 Serpula biplicata Reuss. - Frič, p. 96.

1961 Pomatoceros biplicatus (Reuss, 1845). - Regenhardt, p. 50.

non 1978 Pomatoceros biplicatus (Reuss). - Ziegler, p. 218, figs 1.3 and 2.3 .

non 1984 Pomatoceros biplicatus (Reuss, 1845). - Ziegler, p. 231, pl. 4, fig. 9 .

Material. - One specimen fixed to an inoceramid valve.
Description. - The tube is fixed to the substrate along its whole length, curved, ca $34 \mathrm{~mm}$ long, very slowly increasing in diameter, reaching only $1.3 \mathrm{~mm}$ in width. The tube is somewhat depressed, with a distinct longitudinal keel along its entire length. (Only as a result of diagenetic deformation, the specimen seems to have three longitudinal keels.) Transversal ornamentation consists of two alaeshaped peristomes, strongly resembling the alae of Cementula and Spiraserpula.

Discussion. - The specimen corresponds well with the description and figure given by Reuss. It certainly represents a valid species because it increases much slower in width and remains much more slender than, for example, Neovermilia ampullacea, and due to its keel it clearly differs from the slender tubes of Glomerula.

Considering the generic assignment of this species, its slenderness and the shape of its peristomes point to the Cementula/Spiraserpula group. However, these genera nearly always form spirals, whereas in the specimen from Úpohlavy there is no trace of a spiral. Therefore the generic assignment of this specimen and this species remains doubtful.

\section{Genus Pyrgopolon De Montfort, 1808} Subgenus Pyrgopolon (Septenaria) Regenhardt, 1961

Pyrgopolon (Septenaria) macropus (J. de C. Sowerby, 1829)

Figure 6C

1829 Serpula (Vermilia?) macropus J. de C. Sowerby. Sowerby, p. 200, pl. 597, fig. 6.

non 1883 Serpula macropus Sowerby. - Frič, pp. 128, 129, fig. $115 \mathrm{a}, \mathrm{b}$.

non 1889 Serpula macropus, Sowerby. - Frič, p. 96.

1983 Sclerostyla macropus (Sowerby, 1829). - Jäger, pp. 84-87, pl. 10, figs 6-9.

1991 Sclerostyla macropus (Sowerby, 1829). - Jäger, p. 150 , pl. 4, fig. 12.

1996 Sclerostyla macropus (J. de C. Sowerby, 1829). Radwańska, p. 73, pl. 10, figs 1-9; pl. 12, figs 1-3.

2005 Pyrgopolon (Septenaria) macropus (J. de C. Sowerby, 1829). - Jäger, pp. 188, 189, pl. 9, figs 5-8.

Material. - One specimen of the anterior tube portion with aperture.

Description. - The anterior tube portion is $8.8 \mathrm{~mm}$ long. Width of tube base is $4.6 \mathrm{~mm}$ at the aperture and $4.8 \mathrm{~mm}$ at the opposite end. Tube height reaches $3.8 \mathrm{~mm}$ at the aperture and $5 \mathrm{~mm}$ at the opposite end. The tube is heptagonal in cross-section, and bears a fine but distinct longitudinal 
keel on the upper side and two distinct straight keels on the underside. Lower part of the tube bears two narrower longitudinal lines. Diameter of the circular lumen is $3.4 \mathrm{~mm}$ at the aperture and $3.6 \mathrm{~mm}$ at the opposite end. Longitudinal ornamentation consists of fine, weak but distinct wrinkles.

Discussion. - This is the first find of a true $P$. (S.) macropus in the Upper Turonian of the Bohemian Cretaceous Basin because Serpula macropus (Sowerby) as described by Frič (1883, 1889) does not represent Pyrgopolon (Septenaria) macropus (Sowerby), but Neovermilia ampullacea. Moreover, the species macropus was not mentioned by Ziegler (1984). P. (S.) macropus is well known from the Lower Campanian to the uppermost Upper Maastrichtian and maybe in the Danian. P. (S.) polyforata (Jäger) is distinguished by its "polyforate" structure on the surface of the tube. $P$. ( $S$.) erecta (Goldfuss) is larger in tube diameter (up to $14 \mathrm{~mm}$ ) and occurs in the Upper Maastrichtian. $P$. (S.) voigti Jäger from the Upper Maastrichtian to ?Danian is distinguished by often possessing more than one keel in the fixed tube portion and usually seven low, narrow but distinct longitudinal edges in the free tube portion.

Subfamily Spirorbinae Chamberlin, 1919

Genus Neomicrorbis Rovereto, 1903

\section{Neomicrorbis crenatostriatus crenatostriatus (Münster in Goldfuss, 1831)}

Figures 4A, 6E-G

1831 Serpula crenato-striata Münster. - Goldfuss, p. 239, pl. 71 , fig. 2.

1889 Serpula umbilicata, von Hagenow. - Frič, p. 96.

?1889 Serpula granulata, Sowerby. - Frič, p. 97.

1978 Neomicrorbis crenatostriatus (Münster). - Ziegler, p. 221, pl. 50, fig. 5 .

1983 Neomicrorbis crenatostriatus (Münster in Goldfuss, 1831). - Jäger, pp. 122-125, pl. 15, figs 1-6.

1984 Neomicrorbis crenatostriatus (Münster), 1831. - Ziegler, p. 246, pl. 8, fig. 5.

1984 Neomicrorbis knobi nov. spec. - Ziegler, pp. 246, 247, pl. 8, fig. 6 .

1991 Neomicrorbis crenatostriatus (Münster in Goldfuss, 1831). - Jäger, p. 152, pl. 5, figs 6-8.

2005 Neomicrorbis crenatostriatus crenatostriatus (Münster in Goldfuss, 1831). - Jäger, p. 197, pl. 9, fig. 10.

Material. - 18 tubes. One tube attached to the core of a nautiloid (Eutrephoceras sp.) and one to an ammonite (Lewesiceras $\mathrm{sp}$.), two others to the ostracum of respective inoceramid valves, one to an oyster valve and 13 to two tests of irregular echinoids (Micraster leskei). There are however other specimens not included in the above number which can be observed as imprints in internal moulds of cephalopod shells.

Description. - The tubes are planispiral to low trochospiral, remaining in contact with the substrate even at the aperture, and having a wide umbilicus. Sinistrally and dextrally coiled tubes occur in about equal numbers. Tube diameter varies between 1.5-3 mm. Longitudinal rows of fine granula are usually present already on small diameter tubes, but may appear only at a tube diamter of circa $2 \mathrm{~mm}$ in one specimen.

Discussion. - According to Jäger (1993, 2005) the Late Cretaceous forms described as distinct species crenatostriatus (Münster in Goldfuss, 1831), hagenowii Jäger, 1983 and subrugosus (Münster in Goldfuss, 1831), usually distinguished by their ornamentation, very probably represent one single species. Jäger (1993, 2005) regarded them as ecological varieties or subspecies of a single variable species, N. crenatostriatus. Some observations on recent Spirorbinae support this view: Knight-Jones (1978, p. 234) remarked that "Tubes that usually bear longitudinal ridges commonly lack them in the younger stages of growth (Crisp et al. 1967, Knight-Jones et al. 1974) and may lack them throughout life in areas of reduced water movement (Gee 1964)". However, ontogeny is not the only reason for variation in ornamentation. A different reason may be a difference in ecological conditions, especially in water energy. For example, in late Cretaceous Neomicrorbis, $N$. crenatostriatus subrugosus appears to have preferred a higher energy setting (e.g. rocky coast facies of Velim and Chrtníky localities, and see also Jäger (1983) for localities in northern Germany) than the longitudinally ornamented Neomicrorbis crenatostriatus crenatostriatus. Co-occurrence of both subspecies at the nearshore locality Velim supports the opinion that these forms belong to a single species.

As stated by Jäger (2005) Neomicrorbis knobi Ziegler, 1984 belongs to $N$. crenatostriatus crenatostriatus.

\section{History of research and general discussion}

Although sabellid and serpulid (including spirorbine) taxa have not been previously reported in detail from Úpohlavy quarry, there are a few reports on these polychaetes in hemipelagic sediments of the Bohemian Cretaceous Basin. Here we give a list of species reported by Reuss (1845), Geinitz (1839-1842, 1843, 1875) and Ziegler (1984). Their systematical conclusions are briefly discussed. Original names as well as a brief nomenclatorial revision are presented here (see Systematic Palaeontology section). The main focus is on three pivotal localities - Hudcov, Strehlen and Weinböhla - situated in the broader vicinity 
of the Úpohlavy area. The above mentioned treatises were based on $19^{\text {th }}$ century collections; outcrops of the quarries are no more accessible.

From Hudcov [i.e. "Hundorf"] situated close to Teplice, Geinitz (1839-1842, 1843) described and/or figured "Serpula" gordialis von Schlotheim, gordialis var. infibulata Geinitz, gordialis var. tortuosa Geinitz, plexus Sowerby, pustulosa Geinitz (also in Geinitz 1875), rotula Goldfuss, and amphisbaena Goldfuss (not a serpulid, but a bivalve, later corrected to Gastrochaena amphisbaena by Geinitz himself). From the same locality, Reuss (1845) described and/or figured "Serpula" biplicata Reuss, depressa Goldfuss, rotula Goldfuss, amphisbaena Goldfuss (see comment above), gordialis von Schlotheim, gordialis var. infibulata Geinitz, and pustulosa Geinitz. According to present nomenclature the combined lists of Geinitz and Reuss represent Glomerula plexus, Glomerula lombricus, Serpula? (Cementula?) biplicata, Neovermilia ampullacea, and, perhaps, Dorsoserpula wegneri. From the Hudcov area, Frič (1889) did not list any additional species to those already reported by Reuss and Geinitz, but from the "Teplitzer Schichten" of Bohemia (without accurate details of the location ) he mentioned "Serpula" umbilicata von Hagenow and from Kyselka [i.e. Sauerbrunnberg] near Bílina as well as from Čížkovice, also "Serpula" granulata Sowerby. As both species names are recognized as synonyms of Neomicrorbis crenatostriatus crenatostriatus, the specimens mentioned by Frič (1889) should be allocated to that species and subspecies.

From the Upper Turonian of more than a dozen Bohemian localities Ziegler (1984) listed Glomerula gordialis (von Schlotheim), Jereminella spinari Ziegler (recently recognised by the present authors [T.K. and M.J., unpublished observation] to be an ichnofossil, not a serpulid tube), Spiraserpula subinvoluta (Reuss), Vepreculina soukupi Ziegler, Spirorbis turnoviensis Ziegler, and Neomicrorbis crenatostriatus (Münster in Goldfuss). In actual nomenclature, the authors (T.K. and M.J.) recently synonymised these species with: Glomerula plexus, Glomerula lombricus, Neovermilia ampullacea, Neomicrorbis crenatostriatus crenatostriatus, and Neomicrorbis crenatostriatus subrugosus (Münster in Goldfuss). The last mentioned subspecies is the only one on this list that has not yet been found in Úpohlavy. This subspecies has been identified as the holotype specimen of "Spirorbis turnoviensis" figured by Ziegler (1984) which is from the Middle Turonian of Turnov. Therefore it is beyond any doubt that "Spirorbis turnoviensis" is a junior synonym of N. crenatostriatus subrugosus. However, it is not possible for us to state if those tubes referred by Ziegler to Upper Turonian turnoviensis also belong to the subspecies subrugosus or not, because Ziegler did not figure any of his other turnoviensis tubes. As there is no hard evidence for the occurrence of subrugosus in the Upper Turonian of the BCB, subrugosus is ignored here. Surprisingly, Ziegler (1974, 1984) did not explicitly state that Neovermilia ampullacea was very common in the Upper Turonian of the BCB. He did so only for the Upper Cenomanian, Lower and Middle Turonian. From the Upper Turonian he only mentioned $N$. ampullacea indirectly by its junior synonym, Vepreculina soukupi represented only by a single specimen.

From Strehlen, now a district in the city of Dresden, situated in the Saxonian part of the BCB, Geinitz (1839-1842, 1843) described and/or figured "Serpula" gordialis von Schlotheim, amphisbaena Goldfuss (see comment above), pustulosa Geinitz, erecta Goldfuss, and triangularis Münster in Goldfuss. Later, in 1875, the author extended his species list for the Strehlen locality describing and/or figuring: "Serpula" gordialis von Schlotheim (plexus Sowerby), ampullacea Sowerby, pustulosa Geinitz, macropus Sowerby, granulata Sowerby, and umbilicata von Hagenow. In actual nomenclature this list represents Glomerula plexus, Glomerula lombricus, Neovermilia ampullacea, and Neomicrorbis crenatostriatus crenatostriatus. Frič (1889) cited some of Geinitz's species as only predicted finds within the BCB.

A recent check (M. J.) of Geinitz's material from the Dresden-Strehlen collection as well as those of other $19^{\text {th }}$ and $20^{\text {th }}$ century collectors, housed in the Senckenberg Naturhistorische Sammlungen Dresden, resulted in the following list: Glomerula plexus, Glomerula lombricus, Josephella subanulata Regenhardt, 1961, Neovermilia ampullacea, Dorsoserpula wegneri, and Neomicrorbis crenatostriatus crenatostriatus. A comparison of the final lists for Strehlen and Úpohlavy reveals that there are only three species present at one or the other of the two localities, but not both. These species are very rare in their respective localities: it is presumably only a matter of chance they have not yet been found in the other locality. These species are Josephella subanulata, from Dresden-Strehlen but not Úpohlavy, and Serpula? (Cementula?) biplicata and Pyrgopolon (Septenaria) macropus, described from Úpohlavy in the present paper, but not known from Dresden-Strehlen.

From Weinböhla near Meissen, also situated in the Saxonian part of the BCB, Geinitz (1839-1842, 1875) described and/or figured "Serpula" gordialis von Schlotheim and, only in 1875, "S." macropus Sowerby. According to present nomenclature, this list represents Glomerula plexus, G. lombricus, and Neovermilia ampullacea.

\section{Worms and their substrates - palaeoecological remarks}

The worm-substrate relationship has been at least a partial subject of many papers dealing with polychaetes (e.g. Taylor \& Wilson 2003, Žítt et al. 2003, Žítt \& Vodrážka 2013) 
among other benthic organisms since the 1960s. An exhaustive study of soft-bottom dwellers has recently been published by Seilacher et al. (2008).

This palaeoecological section is almost exclusively based on data from the Úpohlavy outcrops: the main accessible and most completely investigated Upper Turonian locality in the area. Our research concerned mainly the substrate preferences or the life strategies of taxa present at the locality.

The only representatives of the soft-bottom dwelling tubiculous polychaetes rank within the sabellid genus Glomerula. This statement is true not only for Úpohlavy but also extends to the Upper Turonian of the Bohemian Cretaceous Basin (BCB) in general. There are also a few specimens of G. plexus and one of G. lombricus indicated as attached to larger solid substrates (see sections devoted to the individual species - above; and to skeletozoans - below). Larvae of G. plexus frequently attached themselves to relatively tiny substrates such as a small shell fragment or a large foraminifer. During growth, sometimes several of these polychaete individuals crowded together, and created a self-supporting knot-like reeflet (Fig. 3C, D), in which one, rarely more, bioclasts from the close vicinity became integrated (for details of this strategy see also Seilacher et al. 2008). These knots, often slightly elongated, may be quite large and are remarkably common in the $\mathrm{Xb}$ lithounit of the Ohře-Dresden district. In Úpohlavy as well as in other Late Turonian localities in the area (Strehlen, Hudcov) the largest dimension of a knot may exceed $50 \mathrm{~mm}$ in size. There are broken tubes in some of the clusters which are tightly overgrown by other tube meanders and tubes with a narrow lumen growing around large ones. These features provide evidence that the bundles are usually formed by clusters of more individuals (as already stated by Seilacher et al. 2008), although it is very difficult to distinguish between the individuals, or count them. The knot-configuration seems to be rather random or controlled by the shape of the incorporated particles and preceding tubes/tube portions (e.g. Fig. 3D). This thigmotaxis, typical for the glomerulids, is remarkable even in specimens cemented to large substrates (see below) where it often leads to the formation of tight meanders or spirals (e.g. Fig. 3A). The inclination towards a spiral form is indicated even in some of the G. plexus free lying knots (Fig. 3F). In G. lombricus the planispiral (or very low trochospiral) form has been observed in specimens which did not show any signs of attachment to larger hard substrates (Fig. 3G, H). This unattached planispiral growth-mode has not been found in G. plexus. The planispiral shape, however, is far from being obligatory in G. lombricus. As all the studied specimens are either loose knots or spirals, there is no clear evidence if an individual could produce both the knots and planispirals in one tube. Switching of the knot/planispiral mode may represent a response to softground/firmground conditions respectively. G. lombricus and G. plexus both show a tendency to form larger systems of knots connected with straightened "seeking" tube portions. This is well documented in sample NM-O6941 (Fig. 3E) which shows an exceptionally well preserved portion of the tube system with both the knot and "seeking" tubes connected in their more or less contemporary faunal context. The knot serves as a substrate for Gryphaeostrea canaliculata (J. de C. Sowerby, 1829).

In contrast to the sabellid Glomerula, the more diverse serpulids found at Úpohlavy are all obligate encrusters. There are a wide range of substrates occupied by these species such as skeletons of sponges, echinoids and shells of various invertebrates and their fragments. Although there is extensive evidence of dwelling upon hard parts of various organisms post mortem (skeletozoans, see Taylor \& Wilson 2002), no obvious case of settlement on any shells syn vivo has been detected at Úpohlavy.

The post mortal encrustation is obvious on tests of the echinoid Micraster (for Neomicrorbis crenatostriatus crenatostriatus; Fig. $6 \mathrm{E}$ ) as the tests of the echinoids were covered with soft tissue during life, moreover these echinoids were infaunal. Clearly, there are two groups of N. c. crenatostriatus specimens on the figured Micraster test. The size pattern is remarkably bimodal; there are 7 well-built (mature?) tubes (A) and 5 juvenile ones (B) on the collapsed echinoid test. Orientation of the scattered specimens of both the groups seems to be more or less random. There are both dextrally and sinistrally coiled specimens in both the groups. The A-group and the B-group of tubes seem to be settled in two different areas. From the situation described here it is not clear if there are two generations or just one with a different life history. If there were two generations of sclerozoans, it is impossible to judge anything about their succession. There are two different main hypotheses, similar in probability. Firstly, the substrate moved which resulted in the death of B-group specimens or, vice-versa, and a new area was made available for settlement of a second generation (B-group which would have died not fully grown). The second interpretation is that the surface had been partialy overgrown by algae which caused the death of the B-group members. Seasonal algal growth (brown algae) was reported by Terlizzi et al. (2000) as being the main mortality controling factor in shallow-water conditions. Their experiment, focussed on living spirorbins, indicated that rapid growth of these algae (during August at the test location) caused about 74\% mortality of spirorbins on their experimental slabs. Although the experiment was carried out in much shallower conditions, the algae hypothesis should be taken into account to at least about 25-30 m absolute depth (maximum depth for brown algae appearance). This does not however correlate with known data regarding the relative sea-level changes in the area during sedimentation of $\mathrm{Xb} \beta-$ I. labiatoidiformis/striatoconcentricus inoceramid Zone (Laurin \& Vodrážka 2010). 
The skeletozoic mode of life can also be demonstrated in shells of large inoceramids (for $N$. crenatostriatus crenatostriatus, Neovermilia ampullacea; Fig. 4C), where the polychaete tubes are attached to the edges of shell-fragments and/or internal surfaces. Settlement on the inner surfaces of spondylid and cephalopod shells can also be shown in Neovermilia ampullacea and Neomicrorbis c. crenatostriatus (Fig. 4A, D, E). These shells provided ideal shelter for a cryptic existence, but could also help to survival in occasional turbulent events. The mature-worm tubes show that the shells providing shelter to their secondary inhabitants had to have had a vacant interior for some considerable period of time before being filled with sediment. The actuological data given by e.g. Bromley et al. (1989) or Terlizzi et al. (2000) indicate that the exposure had to last more or less continuously for minimally between several weeks to a few months. These evidences come from surfaces of internal moulds found in the $\mathrm{Xb} \alpha$ and lower part of the $\mathrm{Xb} \beta$ unit. Relatively high growth rate at least in epifaunal suspension-feeders is supported by more evidence from the $\mathrm{Xb} \alpha / \mathrm{Xb} \beta$ boundary (e.g. Sklenár \& Zágoršek 2012). Dense polychaete associations - consisting of Neovermilia and Neomicrorbis - are common within the bodychambers of nautiloids (Angulithes, Eutrephoceras) as well as ammonoids (Lewesiceras). Whereas these polychaetes, Neovermilia ampullacea in particular, show remarkable affinity to cephalopod shell interiors there is insufficient evidence to indicate a necroplanktonic life style in these species. On the contrary, the inclination towards life in cryptic conditions at least for $N$. ampullacea is evident.

One of the samples in particular attracted the interest of the authors. This specimen (Fig. 4A), part of an inner mould of a nautiloid (Eutrephoceras? sublaevigatum), shows relicts of two groups of polychaete encrusters. The major group is represented by rather faint imprints of tubes attributed to serpulids Neomicrorbis sp. and Neovermilia ampullacea, the second group involves a single tube of Neomicrorbis c. crenatostriatus attached to the mould from outside. There is a hypothetical possibility that the specimen cemented directly onto the internal mould. This would imply the presence of lithified and exhumed internal moulds on the sea-bottom within the area. As there is no clear evidence of rapid synsedimentary calcite precipitation at a rate strong enough to provide calcified hardgrounds of this character (e.g. Palmer et al. 1988) on the sea bottom of this part of the basin, another processes such as swift phosphatisation or silicification come into consideration.The first phenomenon, moreover synchronous, is well documented from the nearby locality of Býčkovice (Vodrážka et al. 2009), where phosphatised inner moulds served as hard substrates for epilithozoans. Nevertheless, in contrast to the appearance of the sample, analyses performed by electron probe microanalyser as well as photospectrometry have shown that the inner mould has not been phosphatised in any way. Partial silicification and pyritisation has been detected only on the surface of the mould which would not make the object hard enough to remain on the sea bottom for a sufficient time period. Finally, we are inclined to following interpretation that: the Neomicrorbis specimen - primarilly attached to the outer surface of the shell - stayed attached only due to recrystallisation and/or dissolution of the portion of the nautiloid shell beneath the serpulid tube (see also Breton 2006).

Cryptic behaviour seems to be a facultative preference rather than an obligate strategy. On one hand, there is a unique sample of serpulid Neovermilia? sp. tubes which lived inside a shell of the bivalve Spondylus spinosus Sowerby. The specimen is preserved with both its valves closed. The attachment of the serpulid tubes to the inner surface of both valves is clearly visible on the inner mould of the bivalve. During the lifetime of the serpulids, the valves presumably remained slightly open, but later were closed. After burial and filling of the shell interior with sediment, lithification and pyritisation took place. On the other hand, there is another sample of an octocoral encrustation (Fig. 6B) which overgrew an elongated, slender piece of wood (?) or other elongated substrate projecting freely from the seafloor or floating. The bases of the octocoral have been encrusted by a specimen of Neovermilia which thus, in contrast to the foregoing case, lived almost fully exposed.

Skeletozoans have also been indicated on hexactinellid sponges. These substrates (e.g. skeletons of Hillendia, Guettardiscyphia, Pyrospongia, Sporadoscinia) were inhabited especially by facultative encrusters of the species Glomerula plexus. This sabellid behaved in an opportunistic way inhabiting various surfaces of diverse character and scale (see Figs 3, 6Fa) from foraminifers and shell debris (which seem to be the usual primary support for their free lying knots) to oysters, inoceramid shells, sponges and Micraster tests.

The overview of stratigraphical occurrences (Fig. 2) in the Úpohlavy section allows allocation of the present polychaete taxa into two distinct groups: the first (A) containing G. plexus and N. ampullacea with a wide range over the section and the second one (B) consisting of G. lombricus, D. wegneri, S. crenatostriatus, S. biplicata, and $P$. macropus more or less restricted to the $\mathrm{Xb} \alpha / \mathrm{Xb} \beta$ boundary. We interpret the differences in occurrence to be ecological-amplitude dependent, considering the A-group to have a broad amplitude, while the B-group a narrow amplitude to an environmental factor. The dividing line between the two groups crosscuts the sabellid/serpulid as well as the free-lying/encrusting life strategy division. We agree with the opinion of Wiese et al. (2004) who interpreted the diversity and rise in abundance at the boundary as well as the following depression to be a nutrient-flux controlled process. Apparent weak dependence on sub- 
strate strategy of the A- and B-group discrimination reinforces this hypothesis even for the polychaete communities.

\section{Results and conclusions}

Sabellid and serpulid, including spirorbine, worm tubes from the Upper Turonian Teplice Formation of the BCB were revised and determined. Eight species from seven genera have been verified in Late Turonian oryctocenoses of the BCB: sabellids Glomerula plexus (J. de C. Sowerby) and G. lombricus (Defrance) and serpulids Neovermilia ampullacea (J. de C. Sowerby), Dorsoserpula wegneri (Jäger), Serpula? (Cementula?) biplicata (Reuss), Pyrgopolon (Septenaria) macropus (J. de C. Sowerby), Josephella subanulata Regenhardt, and Neomicrorbis crenatostriatus crenatostriatus (Münster in Goldfuss). Of these, the true Pyrgopolon (Septenaria) macropus (J. de C. Sowerby) was recorded in the BCB for the first time. Seven of these species occurring in the Úpohlavy outcrops have been identified, described in detail, systematically revised, figured and their stratigraphical ranges determined.

A detailed palaeoecological and morphological study on sabellid and serpulid worms resulting from data gained from the Úpohlavy fossil record is provided here. Some of the polychaete encrusters (Neovermilia ampullacea and Neomicrorbis c. crenatostriatus) show a tendency towards cryptic behaviour. A preference for settlement in cephalopod-shell interiors is apparent in both species, and is extremely common in N. ampullacea. However, there is no direct evidence of a necroplanktonic mode of life for these species and a cryptic life in sunken vacant shells should be taken as a more justified interpretation. Adaptation of sabellid worms to soft as well as hard substrates was documented. The shape of the Glomerula plexus tube network was illustrated from an exceptionally well preserved sample.

Evaluation of the stratigraphical data obtained at well documented Úpohlavy sections shows apparent abundance as well as a diversity positive peak around the base of the $\mathrm{Xb} \beta$ lithounit. This corresponds with a parallel increase in other benthic suspension-feeder representatives at the locality and has been interpreted as a result of an increase in nutrient content in the environment. Two groups of tubiculous polychaetes have been distinguished with different ecological amplitudes to an environmental factor which in high probability was the trophic conditions.

\section{Acknowledgements}

We are greatly indebted to Harry A. ten Hove from Naturalis Biodiversity Center, Leiden for his kind help and discussion concerning structure of the tube samples of Neovermilia ampullacea, Radek Vodrážka (Czech Geological Survey, Prague) and Michal
Hulla for providing their large serpulid collections from Úpohlavy quarry and Radek Vodrážka, Kamil Zágoršek and Jiř́ Frank (both from National Museum, Prague) for determination of sponges, bryozoans and nautiloids respectively. We would like to express our thanks to reviewers Olev Vinn (University of Tartu) and Jiří Žitt (The Academy of Sciences CR) for their valuable comments. We are also greatful to Boris Ekrt (National Museum) and Radek Labuta for providing samples with serpulid epibionts and for their cooperation during fieldwork and to M. Veselý for providing samples of Neovermilia ampullacea. We are also indebted to Markus Wilmsen and the staff of the Senckenberg Naturhistorische Sammlungen in Dresden for providing access to material from the Saxonian part of the BCB including many original Geinitz specimens. Furthermore we are indebted to Ivo Macek and Michal Pech (National Museum) for instrumental analyses. At last but not at least we feel indebted to staff of Lafarge Cement, a.s., particularly to Pavel Filous and Petr Pergl. This work was financially supported by the Ministry of Culture of the Czech Republic (DKRVO 2013/05, National Museum, 00023272).

\section{References}

Breton, G. 2006. Des épibiontes fixés sur le moule interne d'ammonites de la craie. L'écho des falaises 10, 57-60.

Bromley, R.G., Hanken, N.-M. \& AsgaArd, U. 1989. Shallow marine bioerosion: preliminary results of an experimental study. Bulletin of the Geological Society of Denmark 38, 85-99.

BrünNich Nielsen, K. 1931. Serpulidae from the Senonian and Danian deposits of Denmark. Meddelelser fra Dansk Geologisk Forening 8, 71-113.

Čech, S., Hradecká, L., Laurin, J., S̆TAFFen, Z., Švábenická, L. \& ULIČNÝ, D. 1996. Úpohlavy quarry: record of the late Turonian sea-level oscillations and synsedimentary tectonic activity, 32-42. Stratigraphy and Facies of the Bohemian-Saxonian Cretaceous Basin, Field Trip Guide, $5^{\text {th }}$ International Cretaceous Symposium. Freiberg.

Chamberlin, R.V. 1919. The Annelida Polychaeta of the Albatross Tropical Pacific Expedition, 1891-1905. Memoirs of the Museum of Comparative Zoology, Harvard University 48, $1-514$.

CrisP, D.J., Bailey, J.H. \& Knight-Jones, E.W. 1967. The tube-worm Spirorbis vitreus and its distribution in Britain. Journal of the Marine Biological Association of the United Kingdom 47, 511-521. DOI 10.1017/S0025315400035141

DAY, J.H. 1961. The polychaete fauna of South Africa, 6. Sedentary species dredged off Cape coasts with a few new records from the shore. Journal of the Linnean Society of London, Zoology 44(299), 463-560.

Defrance, M. 1827. Serpule, 549-572. In Levrault, F.G. (ed.) Dictionnaire des sciences naturelles 48. F.G. Levrault, Strasbourg \& Le Normant, Paris.

Ekrt, B., KošŤÁk, M., Mazuch, M., ValíčeK, J., Voigt, S. \& WIESE, F. 2001. Short note on new records of late Turonian (Upper Cretaceous) marine reptile remains from the Úpohlavy quarry (NW Bohemia, Czech Republic). Bulletin of the Czech Geological Survey 76(2), 101-106. 
Fauchald, K. 1977. The Polychaete worms. Definitions and keys to the orders, families and genera. Natural History Museum of Los Angeles County, Science Series 28, 1-190.

FRIČ, A. 1883. Studien im Gebiete der Böhmischen Kreideformation; Palaeontologische Untersuchungen der einzelnen Schichten. III. Die Iserschichten. Archiv der naturwissenschaftlichen Landesdurchforschung von Böhmen 5(2), 1-137.

FRIČ, A. 1889. Studien im Gebiete der Böhmischen Kreideformation; Palaeontologische Untersuchungen der einzelnen Schichten. IV. Die Teplitzer Schichten. Archiv der naturwissenschaftlichen Landesdurchforschung von Böhmen 7(2), 1-120.

FrIČ, A. 1893. Studien im Gebiete der Böhmischen Kreideformation; Palaeontologische Untersuchungen der einzelnen Schichten. V. Priesener Schichten. Archiv der naturwissenschaftlichen Landesdurchforschung von Böhmen 9(1), 1-135.

FrIČ, A. 1911. Studien im Gebiete der Böhmischen Kreideformation. Palaeontologische Untersuchungen der einzelnen Schichten, Ergänzung zu Band 1. Illustriertes Verzeichniss der cenomanen Korycaner Schichten. Archiv der naturwissenschaftlichen Landesdurchforschung von Böhmen 15(1), 1-101.

GeE, J.M. 1964. The British Spirorbinae with a description of S. cuneatus sp. n. and a review of the genus Spirorbis. Proceedings of the Zoological Society of London 143(3), 405-441. DOI 10.1111/j.1469-7998.1964.tb03871.x

GeInITZ, H.B. 1839-1842. Charakteristik der Schichten und Petrefacten des sächsisch-böhmischen Kreidegebirges. 1. Heft 1839: Der Tunnel bei Oberau, in geognostischer Hinsicht, und die dieser Bildung verwandten Ablagerungen zwischen Oberau, Meissen und dem Plauen'schen Grunde bei Dresden, pp. i-iii + 1-30. 2. Heft 1840: A. Das Land zwischen dem Plauen'schen Grunde bei Dresden und Dohna. B. Fische, Crustaceen, Mollusken, pp. [i-iii +] 31-62. 3. Heft 1842: Die sächsisch-böhmische Schweiz, die Oberlausitz und das Innere von Böhmen, pp. 63-116 [and] Index Petrefactorum $e$ Saxoniae et Bohemiae formatione cretacea, pp. i-xxvi. Arnold, Dresden \& Leipzig.

GEINITZ, H.B. 1843. Die Versteinerungen von Kieslingswalda und Nachtrag zur Charakteristik des sächsisch-böhmischen Kreidegebirges, iv +23 pp. Arnold, Dresden \& Leipzig.

GeinitZ, H.B. 1871-1875. Das Elbthalgebirge in Sachsen. Erster Theil, Der untere Quader. Zweiter Theil, Der mittlere und obere Quader. Palaeontographica 20(1-2), $319+245$ pp.

GoldFuss, A. 1826-1844. Petrefacta Germaniae, vii + 252 + iii + $312+$ iv +128 pp. Arnz \& Co., Düsseldorf.

Grube, A.E. 1850. Die Familien der Anneliden. Archiv für Naturgeschichte 16, 249-364.

Hagenow, F. von 1840. Monographie der Rügen'schen KreideVersteinerungen, 2, Radiarien und Annulaten. Neues Jahrbuch für Mineralogie 1840, 631-672.

Hove, H.A. TEn \& Kupriyanova, E.K. 2009. Taxonomy of Serpulidae (Annelida, Polychaeta): The state of affairs. Zootaxa 2036, 1-126.

JÄGER, M. 1983. Serpulidae (Polychaeta, Sedentaria) aus der norddeutschen höheren Oberkreide - Systematik, Stratigraphie, Ökologie. Geologisches Jahrbuch, Reihe A 68, 3-219.

JÄGER, M. 1991. Serpulidae und Spirorbidae (Polychaeta sedentaria) aus dem Alb und der Oberkreide Helgolands (Norddeutschland). Geologisches Jahrbuch, Reihe A 120, 139-175.

JÄGER, M. 1993. Danian Serpulidae and Spirorbidae from NE
Belgium and SE Netherlands: K/T boundary extinction, survival, and origination patterns. Contributions to Tertiary and Quaternary Geology 29(3-4), 73-137.

JÄGER, M. 2005. Serpulidae und Spirorbidae (Polychaeta sedentaria) aus Campan und Maastricht von Norddeutschland, den Niederlanden, Belgien und angrenzenden Gebieten. Geologisches Jahrbuch, Reihe A 157 [for 2004], 121-249.

Knight-Jones, P. 1978. New Spirorbidae (Polychaeta: Sedentaria) from the East Pacific, Atlantic, Indian and Southern Oceans. Zoological Journal of the Linnean Society, London 64, 201-240. DOI 10.1111/j.1096-3642.1978.tb01070.x

Knight-Jones, E.W., Knight-Jones, P. \& Llewellyn, L.C. 1974. Spirorbinae (Polychaeta: Serpulidae) from Southeastern Australia. Notes on their taxonomy, ecology, and distribution. Records of the Australian Museum 29(3), 107-151.

DOI 10.3853/j.0067-1975.29.1974.230

Kočí, T. 2007. Serpulidní červi (Polychaeta, Canalipalpata, Sabellidae, Serpulidae) z činného lomu Úpohlavy (svrchní turon - teplické souvrství), 55-56. In ZLINSKÁ, A. (ed.) Zborník abstraktov z 8. česko-slovensko-polskej paleontologickej konferencii v Bratislave, jún 2007. Štátny geologický ústav Dionýza Štúra Bratislava, Bratislava. [in Czech]

KRUTSKÝ, N. 1972. Stratigrafie a tektonika svrchního turonu v dolním Poohří. Věstník Ústředního ústavu geologického 47, 29-33. [in Czech]

Krutský, N., VÁnĚ, M., HolÁ, A. \& Hercogová, J. 1975. Turon a coniak v dolním Poohří. Sborník geologických věd 27, 99-142. [in Czech]

LAtreille, P.A. 1825. Familles naturelles du règne animal, exposé succinctement et dans un ordre analytique avec l'indication de leurs genres. 570 pp. J.B. Baillière, Paris.

LAurin, J. \& UliČnÝ, D. 2004. Controls on a shallow-water hemipelagic carbonate system adjacent to a siliciclastic margin: example from Late Turonian of Central Europe. Journal of Sedimentary Research 74(5), 697-717. DOI 10.1306/020904740697

LAURIN, J. \& VODRÁŽKA, R. 2010. Record of sea-level fall in shallow-water hemipelagic strata: case study and numerical modelling. Terra Nova 22(2), 103-109. DOI 10.1111/j.1365-3121.2009.00922.x

LinNaeus, C. 1758. Systema Naturae per regna tria naturae, secundum classes, ordines, genera, species, cum characteribus, differentiis, synonymis, locis. Editio decima, reformata. ii +824 pp. Laurentii Salvii, Holmiae.

LommerZHEIM, A. 1979. Monographische Bearbeitung der Serpulidae (Polychaeta sedentaria) aus dem Cenoman (Oberkreide) am Südwestrand des Münsterländer Beckens. Decheniana 132, 110-195.

Marcinowski, R., Walaszyk, I. \& Olszewska-NeJBert, D. 1996. Stratigraphy and regional development of the mid-Cretaceous (Upper Albian through Coniacian) of the Mangyshlak Mountains, Western Kazakhstan. Acta Geologica Polonica 46(1-2), $1-60$.

MiKUlÁš, R. 2006. Ichnofabric and substrate consistency in Upper Turonian carbonates of the Bohemian Cretaceous Basin (Czech Republic). Geologica Carpathica 57(2), 79-90.

Montfort, D. de 1808. Conchyliologie systématique et classification méthodique des coquilles, 1. Coquilles univalves, cloisonées. xxxvii + 409 pp. F. Schoell, Paris. 
Olszewska-NejBert, D. 2007. Late Cretaceous (Turonian-Coniacian) irregular echinoids of western Kazakhstan (Mangyshlak) and southern Poland (Opole). Acta Geologica Polonica 57(1), 1-87.

Palmer, T.J., Hudson, J.D. \& Wilson, M.A. 1988. Palaeoecological evidence for early aragonite dissolution in ancient calcite seas. Nature 335, 809-810. DOI 10.1038/335809a0

PARSCH, K.O.A. 1956. Die Serpuliden-Fauna des südwestdeutschen Jura. Palaeontographica, Abteilung A 107, 211-240.

RADWAŃSKA, U. 1996. Tube-dwelling polychaetes from some Upper Cretaceous sequences of Poland. Acta Geologica Polonica 46(1-2), 61-80.

RAFINESQue, C.S. 1815. Analyse de la nature ou tableau de l'universe et des corps organisés. 224 pp. J. Barrvecchia, Palermo.

Regenhardt, H. 1961. Serpulidae (Polychaeta sedentaria) aus der Kreide Mitteleuropas, ihre ökologische, taxionomische und stratigraphische Bewertung. Mitteilungen aus dem Geologischen Staatsinstitut Hamburg 30, 5-115.

Reuss, A.E. 1840. Die Umgebung von Teplitz und Bilin in Beziehung auf ihre geognostischen Verhältnisse. Geognostische Skizzen aus Böhmen, I. Theil. 298 pp. C.W. Medau, Prag.

Reuss, A.E. 1845-1846. Die Versteinerungen der Böhmischen Kreide-Formation. iv $+58+$ iv +148 pp. E. Schweizerbart, Stuttgart.

Rouse, G.W. \& Fauchald, K. 1997. Cladistics and polychaetes. Zoologica Scripta 26(2), 139-204.

DOI 10.1111/j.1463-6409.1997.tb00412.x

Rovereto, G. 1903. Anellidi del terziario. Rivista Italiana di Paleontologia 9(4), 103-104.

Schlotheim, E.F. von 1820. Die Petrefactenkunde auf ihrem jetzigen Standpunkte. 1xii + 437 pp. Becker, Gotha.

Seilacher, A., Olivero, E.B., Butts, S.H. \& JäGer, M. 2008. Soft-bottom tubeworms: from irregular to programed shell growth. Lethaia 41(4), 349-365. DOI 10.1111/j.1502-3931.2008.00092.x

SklenÁR̆, J. \& Simon, E. 2009. Brachiopod Gyrosoria Cooper, 1973 - a comparative palaeoecological, stratigraphical and taxonomical study. Bulletin of Geosciences 84(3), 437-464. DOI 10.3140/bull.geosci.1102

SKLENÁR̆, J. \& ZÁGORŠEK, K. 2012. Mechovky typu Berenicea (Cyclostomata) z lomu Úpohlavy. Zprávy o geologických výzkumech v roce 2011, 146-148. [in Czech]

SOWERBY, J. DE C. 1829. The mineral conchology of Great Britain 6. 230 pp. J. de C. Sowerby, London.

ŠToRC, R. \& Žítт, J. 2008. Late Turonian ophiuroids (Echinodermata) from the Bohemian Cretaceous Basin, Czech Republic. Bulletin of Geosciences 83(2), 123-140. DOI 10.3140/bull.geosci.2008.02.123

TAYLOR, P.D. \& Wilson, M.A. 2002. A new terminology for marine organisms inhabiting hard surfaces. Palaios 17(5), 522-525.

DOI 10.1669/0883-1351(2002)017<0522:ANTFMO>2.0.CO;2

TAYLOR, P.D. \& WiLSON, M.A. 2003. Palaeoecology and evolution of marine hard substrate communities. Earth Science Reviews 62, 1-103. DOI 10.1016/S0012-8252(02)00131-9

Terlizzi, A., Conte, E. \& Giangrande, A. 2000. Settlement patterns of two Spirorbidae (Annelida, Polychaeta) species in the harbour of Ischia (Gulf of Naples, Mediterranean Sea). Italian
Journal of Zoology 67(3), 303-306.

DOI 10.1080/11250000009356328

VODRÁŽKA, R. 2009. A new method for the extraction of macrofossils from calcareous rocks using sulphuric acid. Palaeontology 52(1), 187-192.

DOI 10.1111/j.1475-4983.2008.00829.x

VodrážKa, R., SkLenÁŘ, J., Čech, S., LAurin, J. \& Hradecká, L. 2009. Phosphatic intraclasts in shallow-water hemipelagic strata: a source of palaecological, taphonomic and biostratigraphic data (Upper Turonian, Bohemian Cretaceous Basin). Cretaceous Research 30, 204-222.

DOI 10.1016/j.cretres.2008.07.007

WARE, S. 1975. British Lower Greensand Serpulidae. Palaeontology 18(1), 93-115.

Wiese, F., Čech, S., Ekrt, B., KošŤÁK, M., Mazuch, M. \& Voigt, S. 2004. The Upper Turonian of the Bohemian Cretaceous Basin (Czech Republic) exemplified by the Úpohlavy working quarry: integrated stratigraphy and palaeoceanography of a gateway to the Tethys. Cretaceous Research 25, 329-352. DOI 10.1016/j.cretres.2004.01.003

ZÁGORŠEK, K., TAYLOR, P.D. \& VodRÁŽKA, R. 2009. Coexistence of symbiotic hydroids (Protulophila) on serpulids and bryozoans in a cryptic habitat at Chrtníky (Lower Turonian, Czech Republic). Bulletin of Geosciences 84(4), 631-636.

DOI 10.3140/bull.geosci.1079

ZaHÁlKA, Č. 1900. Pásmo X (Teplické) křídového útvaru v Poohří. Věstník Královské České společnosti nauk, Tř́ida mathematicko-př́rodovědecká 1899, 1-51.

Zibrowius, H. \& Hove, H.A. TEN 1987. Neovermilia falcigera (Roule, 1898) a deep- and cold-water serpulid polychaete common on the Mediterranean Plio-Pleistocene. Bulletin of the Biological Society of Washington 7, 259-271.

Ziegler, V. 1973. Fauna středního turonu Českého ráje. Die Fauna aus dem Mittelturonien des Böhmisches Paradieses. Část 2. Serpulidae. Práce a studie, Př́roda Pardubice 5, 31-43.

ZIEGLER, V. 1974. Serpula ampullacea Sowerby, 1829 (Polychaeta, Sedentaria) v české křídě. Acta Musei reginaehradecensis 15, 61-64. [in Czech]

ZIEGLER, V. 1978. The significance of the family Serpulidae (Polychaeta, Sedentarida) for stratigraphic correlation of the Bohemian Cretaceous Basin, 217-222. Paleontologická konference '77. Univerzita Karlova, Praha.

ZIEGLER, V. 1984. Family Serpulidae (Polychaeta, Sedentaria) from the Bohemian Cretaceous Basin. Sborník Národního muzea $v$ Praze 39B(4), 213-254.

ŽítT, J., KopÁČovÁ, M. \& NeKovaŘík, Č. 2003. Epibionts of mollusc shells from the Korycany limestones (Upper Cenomanian, Czech Republic). Bulletin of the Czech Geological Survey 78(1), 41-52.

ŽítT, J. \& VodrážKA, R. 2008. New data on Late Turonian crinoids from the Bohemian Cretaceous Basin, Czech Republic. Bulletin of Geosciences 83(3), 311-326. DOI 10.3140/bull.geosci.2008.03.311

ŽítT, J. \& VodrÁŽKA, R. 2013. Terebella phosphatica Leriche (Polychaeta) associated with phosphatic crusts and particles (Lower Turonian, Bohemian Cretaceous Basin, Czech Republic). Cretaceous Research 41, 111-126. DOI 10.1016/j.cretres.2012.11.003 